Çukurova Üniversitesi Eğitim Fakültesi Dergisi

Vol: 50 Numb: 2 Page: 1464-1490

https://dergipark.org.tr/tr/pub/cuefd

\title{
Development of Teachers' Curriculum Implementation Approaches Scale: A Validity and Reliability Study ${ }^{*}$ \\ Gülçin ÇELIKER ERCAN ${ }^{\mathrm{a}^{*}}$ (ORCID ID - 0000-0003-2501-9392) \\ Zühal ÇUBUKÇU ${ }^{\mathrm{b}}$ (ORCID ID - 0000-0002-7612-7759
}

${ }^{a}$ Eskişehir Osmangazi Üniversitesi, Eğitim Fakültesi, Eskişehir/Türkiye

${ }^{\mathrm{b}}$ Eskişehir Osmangazi Üniversitesi, Eğitim Fakültesi, Eskişehir/Türkiye

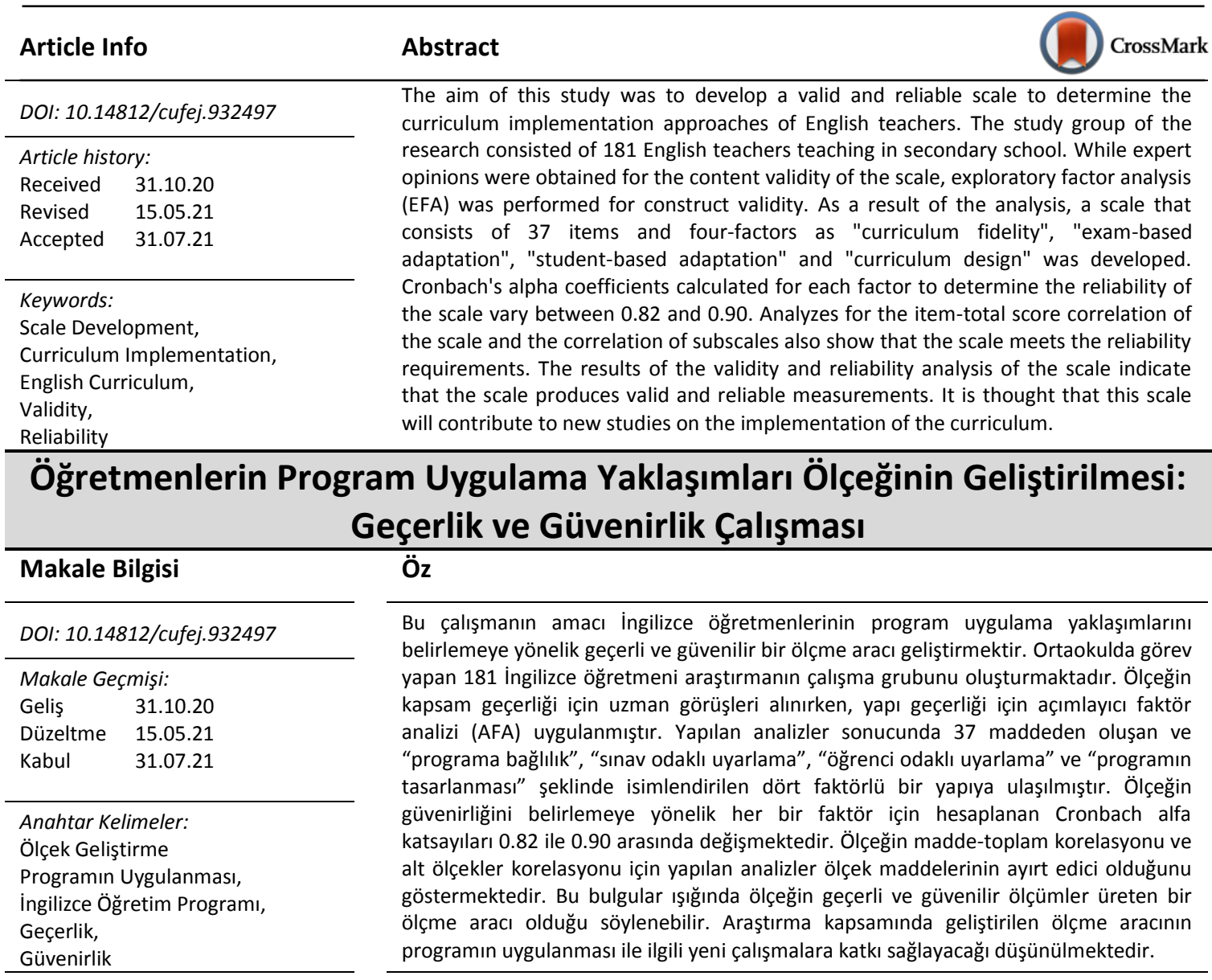

\section{Introduction}

In Turkey, curricula are prepared by the Board of Education under the Ministry of National Education (MNE) and implemented in the whole country with a centralist approach. Regardless of the quality of the curricula prepared in the center, teachers, with their own knowledge, skills, attitudes and behaviors,

*This study was derived from the dctoral thesis of the author.

*Author: gceliker@oguedu.tr 
are better able to identify the best learning experiences for their students (Doll, 1970). Related studies also show that curricula in use are mostly shaped by teachers' own attitudes, beliefs, preferences, perceptions and competencies (Ben-Peretz, 1990; Bümen, Çakar, \& Yıldız, 2014; Meidl \& Meidl, 2011). The fact that teachers substitute their own ideas and competencies for the basic ideas in the curriculum while implementing it in the classroom causes diversity in the implementation of the curriculum (Gökçek, 2008). For this reason, it is necessary to determine the views of teachers on the curriculum and how they reflect their views while implementing it in their classroom (Akpınar, 2011).

Although the curricula are prepared by experts in the center, it is often stated in the studies that they are not effective as expected. In order to understand the reason for this situation, it is necessary to examine the implementation of the curriculum in more detail. An evaluation about the curriculum materials and learning products is not correct without examining how and to what extend theachers implement the curriculum in their classroom (Fullan \& Pomfret, 1977). No matter how perfectly prepared a curriculum is, teachers, who are implementers of the curriculum cannot implement it effectively unless they comprehend the philosophy of the curriculum and the understanding it is based on (Şeker, 2007). Moreover, local differences in student interests, needs and characteristics create difficulties in implementing the curriculum as planned in every school and in every classroom (Bümen, Çakar, \& Yıldız, 2014). Therefore, teachers can transform the official curriculum prepared with a centralized approach into a different form while applying them in their classrooms. This situation reveals the concept of "operational curriculum", one of the curriculum types defined by Posner (1992). Although the official curriculum has been prepared beforehand, the communication between teachers and students with the curriculum constitutes the curriculum in use, in other words, operational curriculum (Shawer, Gilmore, \& Banks-Joseph, 2009). Operational curriculum can be described as a translation of official curriculum into a plan for instruction. Although the same curriculum is implemented in every school and classroom, it has always been a matter of curiosity that students in some classes learn better than other classes. Moreover, we need to understand how different curricula emerge from the implementation of the same official curriculum (Shawer, 2010). At this point, we need to know more about curriculum implementation approaches that have an effect on transforming the official curriculum into a different version in implementation.

When the literature on curriculum implementation approaches is examined, it is seen that teachers either adhere to the curriculum or make adaptations on it (Ben-Peretz, 1990). Researchers who examine the fidelity approach focus on the implementation of official curriculum by teachers in classroom. Those with adaptation approach state that the curriculum changes can be reflected in schools, but the curricula should be adapted appropriately to the school (Bümen, Çakar \& Yıldız, 2014). A third approach, emphasizing the will of the teacher in the implementation of the curriculum, was added by Synder, Bolin, and Zumwalt (1992) to the approaches to fidelity and adaptation. According to this third approach, teachers act like curriculum development experts who make significant changes in the curriculum and build it based on student experiences. The curriculum is a product of teacher and student experiences. Shawer (2003), as a result of his study on teachers who teach English as a foreign language, stated that teachers approach the curriculum in different ways such as curriculum transmitters, curriculum developers and curriculum makers while implemening it in their classes (cited in Shawer, Gilmore, \& Banks-Joseph, 2008). Accordingly, teachers who transfer the curriculum adhere to the curriculum materials one-on-one in the implementation of it, while those who develop the curriculum make adaptations in the curriculum materials such as skipping, removing, providing additional resources and activities in line with the student needs and interests. Those who make the curriculum determine the exercises to be carried out in the classroom based on the student experiences and their own attitudes, beliefs and experiences.

Snyder, Bolin, and Zumwalt (1992) stated that teachers adopted three different curriculum approaches, namely fidelity, mutual adaptation, and enact in the implementation of the curriculum, and defined teacher behaviors belonging to each approach. Teachers who adopt the fidelity approach in the implementation of the curriculum are transmitters who only provide the curriculum materials. These teachers convey the objectives and content of the official curriculum as they are given. They follow the 
student textbook and the teacher's guide book in teaching and do not present new material or content other than these curriculum materials. They transfer the content of the textbook unit by unit, page by page. They focus solely on content and rarely complete missing elements, without responding to classroom dynamics. In teaching, they stick to the activities in the textbook or teacher's guide book. Since they teach based on a textbook, it is usually clear what and how to teach in the next lesson. In the classrooms of these teachers, learning is mostly for passing the exam or the lesson. Teachers who adopt the mutual adaptation approach are adapters who make arrangements in the curriculum and they have a more active role while implementing it in their classrooms. They skip some chapters in the textbook, add topics that are not in the textbook, bring materials/activities outside the scope of the curriculum. In short, they become curriculum developers using a variety of resources in addition to curriculum materials. Student experiences are important resources in teaching. Teachers who enact curriculum act like curriculum development experts who make decisions about the curriculum and make significant changes on it. In this approach, the curriculum is created jointly by teachers and students. Curriculum knowledge is no longer a product, but structures composed of experiences created by teachers and students. In this approach, teachers often plan instruction without referring to printed curriculum materials.

When the studies on the implementation of the curriculum in Turkey are examined, there is no research directly aimed at determining the teachers' approach to curriculum implementation. However, three different teacher profiles were determined by Tokgöz (2013) based on the similarities and differences of teachers in the implementation of the curriculum and these profiles were named as curriculum followers, curriculum extenders and curriculum adapters. According to this classification, those who follow the curriculum adhere to the curriculum materials as in other classifications in the literature, while those who adapt the curriculum make up for the deficiencies in the curriculum materials with other resources or their own experiences. Those who expand the curriculum in this classification focus on student success and therefore, while implementing the curriculum in their classrooms, they prioritize knowledge transfer in order to increase the success of students in national exams and improve their exam performance.

On the other hand, while there are direct studies in the foreign literature on determining teachers' approaches to curriculum implementation and examining the effects of these approaches on teachers and students (Shawer, 2010; Shawer, Gilmore, \& Banks-Joseph, 2008; 2009; Snyder, Bolin, \& Zumwalt, 1992), in Turkey it is noteworthy that the literature on the implementation of the curriculum is limited with the level of implementation of the constructivist activities generally adopted in the renewed curriculum, and the determination of the teachers' views on the implementation of the curriculum and the problems they experience (Adıgüzel, 2009; Aydemir, Aykaç, \& Ulubey, 2012; Gürel, \& Demirhanİşcan, 2020; Karacaoğlu, \& Acar, 2010; Saraç, \& Yıldııım, 2019; Tekbıyık, \& Akdeniz, 2008; Yaşar, 2012). It is thought that the scale developed within the scope of this research will contribute to further studies for the implementation of the curriculum, such as determining the teacher approaches in large sample groups and examining the effects of teachers' curriculum implementation approaches on students, teachers and schools. Based on this deficiency in the literature on the implementation of the curriculum in Turkey, in this study, it is aimed to develop a valid and reliable measurement tool that helps to determine the curriculum implementation approaches adopted by English teachers while applying the relevant curriculum in their classes.

\section{Method}

\section{Research Model}

This research is a scale development study. During the scale development process, the literature on teachers' curriculum approaches while implementing the curriculum was reviewed and the scale items were determined. After expert opinion was taken on these items, a pilot scale form was created. Then, factor analysis was performed by conducting the trial application of the candidate scale on the appropriate sample, and the experimental form was obtained. In this direction, this study was designed by adopting the experimental process (Yurdugül, 2012). 


\section{Study Group}

This study was limited to the seventh grade English curriculum in order to determine the teachers' curriculum implementation approaches. So, it was aimed for all teachers to answer the scale items by considering the same curriculum. The reason for the preference of the seventh grade curriculum was that the education in the seventh grade is less exam-oriented compared to the education in the eighth grade. Thus, it was aimed that teachers rate the expressions in the scale items without under the pressure of exams, taking into account the applications they make in general.

Since the research was limited to the English teachers teaching in the seventh grade of secondary school, the number of teachers to be reached has become limited. However it is necessary to reach a certain number of teachers in order to carry out the validity and reliability studies of the items in the scale. Therefore, in order to facilitate data collection, it was tried to reach all teachers with the convenience sampling method. In this context, a total of 66 secondary schools, including 57 state schools and 9 private schools, located in Tepebaşı and Odunpazarı central districts of Eskişehir province were attended and 181 English teachers who were teaching in seventh grade and volunteering to participate in the study were included in the study. 153 of the teachers (84.5\%) in the study group were female and 28 (15.5\%) were male. 162 of these teachers (89.5\%) were working in public school and 19 $(10.5 \%)$ were in private schools.

\section{Actions Taken Before Data Collection}

Within the scope of the research, while writing scale items, both the literature on teachers' curriculum implementation approaches (Ben-Peretz, 1990; Bümen, Çakar, \& Yıldız, 2014; Çeliker-Ercan, 2019; Çobanoğlu, 2011; Drake, \& Sherin , 2006; Dusenbury, Brannigan, Falco, \& Hansen, 2003; Kabaoğlu, 2015; Kaya, Çetin, \& Yıldırım, 2012; Shawer, Gilmore, \& Banks-Joseph, 2008; Snyder, Bolin, \& Zumwalt, 1992; Tokgöz, 2013), and the features of the current English curriculum were taken into consideration. Moreover, the qualitative data obtained from long-term observations and interviews conducted by the researcher with teachers in classrooms to determine their curriculum implementation approaches were used while forming scale items.

The relevant literature on the curriculum implementation approaches of teachers is mainly discussed in foreign studies, and studies on this issue in Turkey are quite limited. Therefore, with the assumption that teachers' curriculum implementation approaches in the group to which the scale will be applied may differ from the literature abroad, such a qualitative study was needed before writing the items of the scale. In this direction, a qualitative study was conducted with a total of 14 English teachers working in low, medium and high achievement level secondary schools and also private schools in Tepebaşı and Odunpazarı districts of Eskişehir province with the maximum variety sampling technique. In this study, it was aimed to determine the curriculum implementation approaches of teachers by examining how they applied the seventh-grade English curriculum in their classes through long-term observation, teacher and student interviews. As a result of the analysis of the data obtained, it was seen that the teachers in the study group had three different approaches: curriculum fidelity, curriculum adaptation, curriculum design. In each three approaches, teachers make student-based and exam-based implementations which emerge more clearly especially in curriculum adaptation approach. The characteristics of the teacher with each approach are briefly explained below.

Teachers who have curriculum fidelity approach adhere to the official curriculum and curriculum materials. These teachers only include materials prepared in line with curriculum in their lessons and apply the activities in these materials without making any adaptation. In addition, as the curriculum suggests, they also include communication-oriented activities such as listening and speaking and consider process evaluation during evaluation processes. On the other hand, since these teachers adhere to the curriculum and curriculum materials, they ignore student needs and interests, paying attention to the implementation of only the objectives, content and activities in curriculum materials.

Teachers who have curriculum adaptation approach make adaptations on curriculum and on the objectives, content, activities etc. in the textbooks prepared within the scope of the official curriculum. 
Teachers make these adaptations either to meet student needs and interests or to prepare students for exams. Teachers, who have a student-based adaptation approach, use curriculum materials in their classrooms, and make changes in the activities in these materials in line with the interests, needs and requests of the students. These teachers can skip the activity when the activity in the book is not suitable for the level of the student, they can simplify the activity or change it with another activity. In addition, these teachers bring materials and activities to the classroom in addition to the activities in the textbook in order to attract students' attention and increase motivation to the lesson. In short, these teachers make changes in the curriculum and textbooks by taking student characteristics into account. On the other hand, the main purpose of the change made by teachers with an exam-based adaptation approach is to prepare students for the exam. Teachers who adopt this approach pay attention to the fact that the relevant curriculum and curriculum materials will be taken into account in national exams, and thus the content and objectives in these materials are given in detail and they ignore activities related to communication skills such as listening and speaking as they are not evaluated in the exam. For this reason, they often skip these activities in the textbook or ignore the communicative purpose of the activity by focusing only on the grammar patterns and words used in these activities. In the said program, it is emphasized that English is not taught as a lesson, but seen as a communication tool. However, these teachers consider English as a lesson that should be memorized by including detailed grammar lectures in order to prepare students for the exam. Since they do not tolerate students' mistakes, they usually correct them immediately. Morever, contrary to what is stated in the curriculum, since they focus more on lecturing in their lessons, they mainly use Turkish in their classes.

Teachers who have curriculum design approach do not apply the official curriculum and curriculum materials in their classroom. Depending on the curriculum implementation policy of the institution (private school) they work for, these teachers usually use another source in their lessons. The objectives and themes they include in the course are different from those specified in the curriculum materials. These teachers usually shape their in-class activities with their students in line with student needs and interests.

While determining the scale items, the findings of qualitative study previously carried out by the researcher was considered and statements were written on the planning of teaching, the materials used, the objectives, content, teaching-learning activities, assessment and evaluation. Finally 62 statements written for the scale were presented to five experts, who have studies on educational sciences, for the content validity. In line with the expert opinions regarding the representation level and clarity, seven of the items that were irrelevant or unnecessary to the subject to be measured were removed from the scale form, and some statements were rewritten to be more understandable. After the expert opinion, the scale form was sent to five different English teachers who were teaching at the seventh grade of secondary school, and opinions were taken regarding the clarity and appropriateness of the scale items. Finally, the scale form was sent to two different experts in the field of Turkish education to check language and understandability. In line with the feedback from English teachers and experts, the spelling mistakes in the scale items were corrected and some expressions that were not understood by the teachers were rewritten taking into account the suggestions. After the corrections in the scale items, each statement in the 5-point Likert scale was rated as (1) Never, (2) Rarely, (3) Sometimes, (4) Frequently, (5) Always. The final scale form with 55 items was created and the application phase of the scale started.

\section{Data Collection and Analysis}

In this study, the final scale form consisting of 55 items was applied to 181 English teachers who were teaching in the seventh grade of secondary school. During the application process, the researcher went to the schools and gave the scale to the teachers and asked them to answer the scale appropriately by informing them about the subject. The collection of research data took two months in November-December of the 2018-2019 academic year, and the time needed to anwer the scale was about 15-20 minutes. In the process of scale development, it is important to carry out validity and reliability studies of the developed scale in order to obtain a measurement tool that produces valid and 
reliable measurements. In this study, the validity was ensured by content validity and construct validity analyzes and the reliability was ensured by internal consistency methods.

\section{Findings}

\section{Findings Regarding the Validity of the Scale}

In this part, the finding regarding the content and construct validity of the scale were presented. An exploratory factor analysis (EFA) was conducted to examine the construct validity of the scale developed within the scope of this research. Before EFA application, necessary assumptions such as missing values, sample size, homogeneity, normality and linearity were examined to determine the suitability of the data set to factor analysis. First of all, the average values were assigned to the items with missing values and the data set was made ready for analysis. Kaiser Meyer Olkin (KMO) and Bartlett test results were taken into consideration to test the suitability of the sample size to apply factor analysis. $\mathrm{KMO}=0.817$, $X 2=5353.073, s d=1485$ and Bartlett $(p=.000<0.01)$ values obtained as a result of EFA showed that the sample was sufficient to perform EFA. Levene test results were used to test the homogeneity of the data. Levene test results showed that the dependent variables in the data set have equal variance in the independent variable groups, that is, they are homogeneous ( $p>0.05$ ). Kurtosis/skewness values were considered in the examination of the normal distribution. Although kurtosis values between \pm 1.0 are generally accepted as perfect, values between \pm 2.0 are also accepted in most cases (George \& Mallery, 2016). However, it is stated that variables with kurtosis in the range of \pm 3.0 come from a typical normal distribution (Kalaycı, 2010). The kurtosis/skewness values of the data obtained within the scope of this study are among the acceptable values, so the data meet the normal distribution assumption.

While determining the factor pattern of the scale, principal component analysis was applied and maximum variability (varimax), one of the orthogonal rotation methods, was used as the rotation method. Factor is the name given to a cluster of items with high correlation (Çokluk, Şekercioğlu, \& Büyüköztürk, 2014). As a result of the first EFA, it was seen that the expressions in the scale were distributed meaninglessly under 13 factors with eigenvalues higher than 1 . Deciding on the number of factors based on eigenvalues may not always give reliable results (Green \& Salkind, 2005). Therefore, in determining the number of factors, the percentage of additional variance explained by the factors and the results of scree plot were taken into account.

When the contribution of the factors to the explanation of the total variance falls below $5 \%$, it is decided that the previous factor is the last factor (Can, 2013). In this direction, it was seen that the contribution of the factors after the fourth factor to the total variance was less than $5 \%$. The scree plot makes the relative importance of each factor more apparent by transforming the eigenvalues into a graph (Field, 2009). In scree plot, the breaking point, where the slope of the line changes dramatically, is used to determine the number of factors. The lines between the points before the last point where the line begins to take a horizontal shape indicate the factor number. In this direction, the scree plot given in Figure 1 shows that the items in the scale are gathered under 4 factors. 


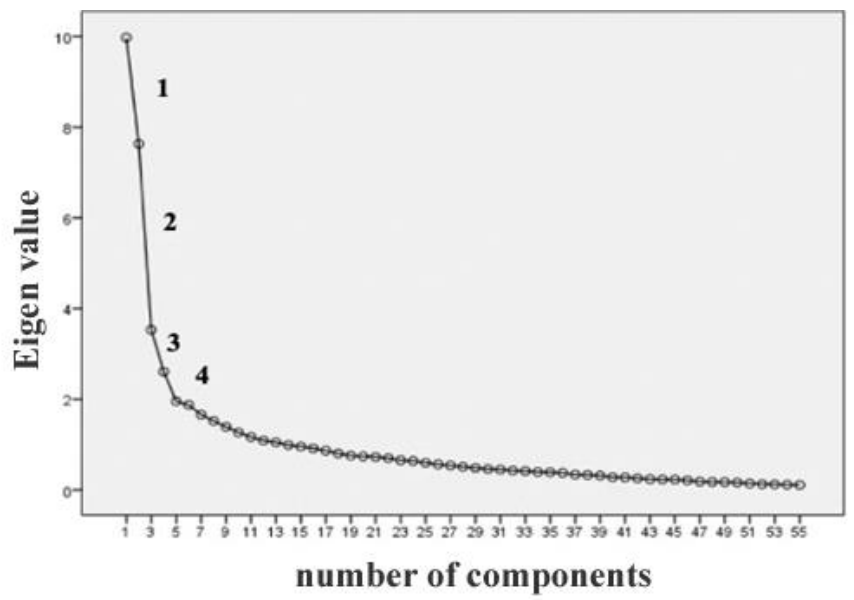

Figure 1. Scree plot showing the number of factors

The number of factors was determined as four, considering the scree plot and the individual contribution of the factors to the total variance. Determining the number of factors as four is also meaningful in terms of being compatible with the expected number in the theoretical structure determined in the writing of the scale items. Therefore, EFA was repeated with four factors. As a result of the repeated analysis for four factors, it was seen that the contribution of the factors to the total variance was $15.64 \%$ for the first factor, $13.54 \%$ for the second factor, $12.73 \%$ for the third factor, and $8.72 \%$ for the fourth factor. The total contribution of these four factors to the common variance is $50.62 \%$. In EFA studies, the lower limit of the factor explaining total variance is accepted as $40 \%$ (Kline, 1994, cited in Karadağ, 2009). Therefore, the total variance value explained by the sub-factors is sufficient. Table 1 shows the variance amounts explained and the eigenvalues of the 4 factors in the scale at the beginning and after the rotation.

Table 1.

Eigenvalues and variance percentages of the factors in the teachers' curriculum implementation scale

\begin{tabular}{cccccccccc}
\hline Factor & \multicolumn{3}{c}{ Initial Eigenvalues } & \multicolumn{3}{c}{ Total Factor Loads } & \multicolumn{2}{c}{ Total Factor Loads After Rotation } \\
\hline & Total & $\begin{array}{c}\text { Variance } \\
\%\end{array}$ & $\begin{array}{c}\text { Cumulative } \\
\%\end{array}$ & Total & $\begin{array}{c}\text { Variance } \\
\%\end{array}$ & $\begin{array}{c}\text { Cumulative } \\
\%\end{array}$ & Total & $\begin{array}{c}\text { Variance } \\
\%\end{array}$ & $\begin{array}{c}\text { Cumulative } \\
\%\end{array}$ \\
\hline 1 & 7,756 & 20,962 & 20,962 & 7,756 & 20,962 & 20,962 & 5,785 & 15,635 & 15,635 \\
2 & 6,005 & 16,229 & 37,191 & 6,005 & 16,229 & 37,191 & 5,009 & 13,539 & 29,174 \\
3 & 2,732 & 7,385 & 44,576 & 2,732 & 7,385 & 44,576 & 4,709 & 12,728 & 41,901 \\
4 & 2,236 & 6,044 & 50,620 & 2,236 & 6,044 & 50,620 & 3,226 & 8,718 & $\mathbf{5 0 , 6 2 0}$ \\
5 & 1,429 & 3,862 & 54,481 & & & & & & \\
6
\end{tabular}

In this study, the acceptance level for the factor load values of the items in the scale was determined to be 0.50 . Factor load value is a coefficient that explains the relationship of items with factors, and it is expected that the load values of the items in the factors they belong to are high (Kleine, 2014). When the literature is examined, there is a common opinion that the factor load value should be at least 0.30 . However, it is necessary to consider the sample size while deciding on the factor load value (Field, 2009). Although there are many opinions regarding these values, Kim-Yin (2004, Cited in Şencan, 2005) explained the factor load values that should be taken into account for certain sample sizes when deciding whether to exclude an item from the scale. Accordingly, if the sample size is less than 350 , the factor load is 0.30; if it is at least 200, factor load is 0.40; if it is at least 120, the factor load is 0.50 ; if it is at least 85 , the factor load should be 0.60 , and if it is at least 60 , the factor load should be 0.70 . Within 
ÇELIKER ERCAN \& ÇUBUKÇU - Çukurova Üniversitesi Eğitim Fakültesi Dergisi, 50(2), 2021, 1464-1490

the scope of this study, since the sample size is 181 , determining the factor load value as 0.50 was considered appropriate. As a result of the analysis, a total of 18 items that do not meet the acceptance level of the factor load value and that show overlapping despite meeting this value were removed from the scale. As a result of excluding these items from the analysis, the factor pattern obtained from 37 items, the factor load values and common factor variances of these items are given in Table 2.

Table 2.

Factor pattern of the the teachers' curriculum implementation scale

\begin{tabular}{|c|c|c|c|c|c|c|}
\hline \multirow[b]{2}{*}{ Row } & \multirow[b]{2}{*}{ Item } & \multicolumn{4}{|c|}{ Subscales } & \multirow{2}{*}{$\begin{array}{c}\text { Common } \\
\text { Factor } \\
\text { Variance }\end{array}$} \\
\hline & & $\begin{array}{c}\text { Curriculum } \\
\text { Design }\end{array}$ & $\begin{array}{c}\text { Student-based } \\
\text { Adaptation }\end{array}$ & $\begin{array}{c}\text { Exam-based } \\
\text { Adaptation }\end{array}$ & $\begin{array}{c}\text { Curriculum } \\
\text { Fidelity }\end{array}$ & \\
\hline & & Factor Load & Factor Load & Factor Load & Factor Load & \\
\hline 1 & 6 & ,796 & & & & ,663 \\
\hline 2 & 11 & ,786 & & & & ,667 \\
\hline 3 & 21 & ,748 & & & & ,653 \\
\hline 4 & 14 & ,732 & & & & 660 \\
\hline 5 & 8 & ,703 & & & & 629 \\
\hline 6 & 2 & 694 & & & &, 576 \\
\hline 7 & 55 & 676 & & & & ,470 \\
\hline 8 & 41 & ,669 & & & & ,511 \\
\hline 9 & 1 &, 557 & & & & ,393 \\
\hline 10 & 38 & & ,718 & & & ,533 \\
\hline 11 & 35 & & 691 & & &, 508 \\
\hline 12 & 34 & & 689 & & & 492 \\
\hline 13 & 36 & & 685 & & & ,501 \\
\hline 14 & 19 & & 596 & & & ,572 \\
\hline 15 & 53 & & 570 & & & 357, \\
\hline 16 & 37 & & 556 & & & 317 \\
\hline 17 & 9 & & ,552 & & & 347 \\
\hline 18 & 7 & & ,537 & & & ,334 \\
\hline 19 & 18 & & ,530 & & & ,409 \\
\hline 20 & 20 & & ,510 & & & ,410 \\
\hline 21 & 13 & & 507 & & & 448 \\
\hline 24 & 23 & & & 689, & & ,520 \\
\hline 25 & 47 & & & 651 & & ,449 \\
\hline 26 & 39 & & & 631 & & ,440 \\
\hline 27 & 10 & & & 627 & & 458 \\
\hline 28 & 54 & & & 608 & & 410 \\
\hline 29 & 46 & & & 602 & & 481 \\
\hline 30 & 5 & & & ,594 & & ,448 \\
\hline 31 & 48 & & & ,566 & & ,460 \\
\hline 32 & 26 & & & & 755, & 665 \\
\hline 33 & 24 & & & & 755 & 666 \\
\hline 34 & 45 & & & & 723 & 591 \\
\hline 35 & 25 & & & & ,643 & 674 \\
\hline 36 & 29 & & & & 615, & 502 \\
\hline 37 & 17 & & & & ,507 & ,446 \\
\hline
\end{tabular}

As a result of EFA, it was seen that each item was theoretically under its own factor. Factors were named by examining the items in each factor. Factor loadings of 9 items under the first factor vary between 0.56 and 0.80 . The statement "I plan my lesson independent from curriculum materials" which is the item 6 under this factor has the highest factor load. When the other items under the first factor are examined together with this item, it is seen that these statements in these items indicate the teachers who do not depend on the textbooks provided by the Ministry of Education in their classroom practices and implement in-class activities with the help of sources which are quite different from 
curriculum materials. For this reason, the first factor was named as "curriculum design". The concept of design here is more oriented towards teaching activities of the teacher. In other words, the teacher designs her teaching in a different way from the official curriculum by making use of her own teaching experiences and materials which are quite different from the ones provided by MNE. The factor loads of 12 items under the second factor ranged from 0.51 to 0.72 . The statement "In my class, I include additional activities in which the student will be active, such as playing games, watching videos, listening to songs, and competing, apart from the ones in curriculum materials", which is the item 38 under this factor, has the highest factor load. When the other items under the second factor are examined together with this item, it is seen that these statements in these items indicate the teachers who use the materials provided by the Ministry of National Education while applying the curriculum in their classrooms, but make adaptations in line with the student profile while applying them in their classrooms. Thus, the second factor was named as "student-based adaptation". Factor loads of 10 items under the third factor ranged from 0.57 to 0.71 . The statement "While studying on the objectives, I put more emphasis on the skill areas which are assessed in national exams", which is the item 16 under this factor, has the highest factor load. When the other items under the third factor are examined together with this item, it is seen that these statements in these items indicate the teachers who use the materials provided by the Ministry of National Education while applying the curriculum in their classrooms, but make adaptations in these materials to prepare students for the exams. Therefore the third factor was named as "student-based adaptation". In the fourth factor, which is the last, there are 6 items with factor loads ranging from 0.51 to 0.76 . The statement "I apply the activities in the curriculum materials in my class as it is stated, without making any changes", which is the item 26 under this factor, has the highest factor load. When the other items under the fourthfactor are examined together with this item, it is seen that these statements in these items indicate the teachers who strictly adhere to the curriculum materials provided by MNE while implementing the curriculum. For this reason, the fourth factor was named "curriculum fidelity". The final edited version of the scale with the items under each factor is given in Appendix-1.

\section{Findings Regarding the Reliability of the Scale}

The reliability analyzes of the scale developed in this study were examined with Cronbach's Alpha value, item-total correlation and subscales correlation within the scope of internal consistency reliability. It is accepted that the scale is reliable when the Cronbach alpha coefficient is 0.70 and above (Durmuş, Yurtkoru, \& Çinko, 2011). The Cronbach Alpha coefficients calculated for the sub-dimensions of the scale developed within the scope of this study vary between 0.82 and 0.90 . Cronbach's Alpha coefficients calculated for all sub-factors of the scale are given in Table 3.

Table 3.

Cronbach alpha reliability coefficients of teachers' curriculum implementation approach subscales

\begin{tabular}{cccc}
\hline & Factors & Items & Cronbach Alfa Coefficient \\
\hline 1 & Curriculum Design & 9 & .903 \\
2 & Student-based & 12 & .861 \\
& Adapotation & & \\
3 & Exam-based Adaptation & 10 & .847 \\
4 & Curriculum Fidelity & 6 & .821 \\
\hline
\end{tabular}

If the item-total correlation coefficient is below 0.30 or negative, it indicates that there is a problem with the related items (Field, 2002, cited in Şencan, 2005). As a result of the item-total score correlation analysis, the correlation coefficients were between 0.55 and 0.83 for the "curriculum design" subdimension; between 0.52 to 0.74 for the "student-based adaptation" sub-dimension; between 0.57 and 0.72 for the "exam-based adaptation" sub-dimension and between 0.62 and 0.83 for the "curriculum fidelity" sub-dimension, it was found to be positive and statistically significant for all items $(p<0.01$; $p=0.00$ ). This shows that the scale provides item-total correlation reliability within the scope of its sub- 
ÇELIKER ERCAN \& ÇUBUKÇU - Çukurova Üniversitesi Eğitim Fakültesi Dergisi, 50(2), 2021, 1464-1490

dimensions. The item-total correlation coefficients of all items in the sub-dimensions of the scale are given in Table 4.

Table 4.

Pearson product-moment correlation analysis results made to determine the item-total correlations of teachers' curriculum implementation approaches scale*

\begin{tabular}{|c|c|c|c|c|c|c|}
\hline & ITEMS & $\begin{array}{l}\text { TOTAL } \\
\text { ITEM-r }\end{array}$ & ITEMS & $\begin{array}{l}\text { TOTAL } \\
\text { ITEM-r }\end{array}$ & ITEMS & $\begin{array}{l}\text { TOTAL } \\
\text { ITEM-r }\end{array}$ \\
\hline \multirow{3}{*}{$\begin{array}{l}\text { Curriculum } \\
\text { Design }\end{array}$} & Item 1 & $0,546 * *$ & Item 8 & $0,769 * *$ & Item 21 & $0,828 * *$ \\
\hline & Item 2 & $0,766 * *$ & Item 11 & $0,834 * *$ & Item 41 & $0,709 * *$ \\
\hline & Item 6 & $0,812^{* *}$ & Item 14 & $0,800 * *$ & Item 55 & $0,676 * *$ \\
\hline \multirow{4}{*}{$\begin{array}{l}\text { Student-based } \\
\text { Adaptation }\end{array}$} & Item 7 & $0,602 * *$ & Item 19 & $0,743 * *$ & Item 36 & $0,709 * *$ \\
\hline & Item 9 & $0,515^{* *}$ & Item 20 & $0,605^{* *}$ & Item 37 & $0,568 * *$ \\
\hline & Item 13 & $0,651^{* *}$ & Item 34 & $0,626^{* *}$ & Item 38 & $0,621 * *$ \\
\hline & Item 18 & $0,646 * *$ & Item 35 & $0,675 * *$ & Item 53 & $0,583 * *$ \\
\hline \multirow{4}{*}{$\begin{array}{l}\text { Exam-based } \\
\text { Adaptation }\end{array}$} & Item 5 & $0,608 * *$ & Item 39 & $0,656^{* *}$ & Item 48 & $0,567 * *$ \\
\hline & Item 10 & $0,644 * *$ & Item 40 & $0,723 * *$ & Item 54 & $0,653^{* *}$ \\
\hline & Item 16 & $0,703 * *$ & Item 46 & $0,615^{* *}$ & & \\
\hline & Item 23 & $0,698 * *$ & Item 47 & $0,668 * *$ & & \\
\hline \multirow{2}{*}{$\begin{array}{l}\text { Curriculum } \\
\text { Fidelity }\end{array}$} & Item 17 & $0,682 * *$ & Item 25 & $0,765^{* *}$ & Item 29 & $0,617 * *$ \\
\hline & Item 24 & $0,773 * *$ & Item 26 & $0,833^{* *}$ & Item 45 & $0,714^{* *}$ \\
\hline
\end{tabular}

* Since there was no total score to be obtained from the entire form, item-total score correlations were calculated as item-subscale total score.

Pearson product-moment correlation analysis was performed to determine the relationship between the subscales in the scale within the scope of subscales correlation. Correlations between subscale scores range from -0.11 to -0.47 . As a result of the analysis, it was observed that the correlation in all other subscales was statistically significant $(p<0.01 ; p=0.00)$, except for the correlation between the student-based adaptation subscale and the curriculum fidelity subscale. A total score cannot be obtained from this scale, and theoretically, no relationship is predicted between all factors in the scale. While there is a relationship between some factors in the scale, since there is no relationship between some of them on both the theoretical and data basis, varimax, one of the vertical rotation methods, was used instead of oblimin while determining the factor pattern of the scale. The correlation coefficients of the subscales with each other are given in Table 5.

Table 5.

Pearson's product-moment correlation analysis results for the subscales correlation of the teachers' curriculum implementation approaches scale

\begin{tabular}{lcccc}
\hline & $\begin{array}{c}\text { Curriculum } \\
\text { Design }\end{array}$ & $\begin{array}{c}\text { Student-based } \\
\text { Adaptation }\end{array}$ & $\begin{array}{c}\text { Exam-based } \\
\text { Adaptation }\end{array}$ & $\begin{array}{c}\text { Curriculum } \\
\text { Fidelity }\end{array}$ \\
\hline CurriculumDesign & 1 & $0,36^{* *}$ & $-0,18^{*}$ & $-0,47^{* *}$ \\
Student-based Adaptation & & 1 & $0,21^{* *}$ & $-0,11$ \\
Exam-based Adaptation & & & 1 & $0,23^{* *}$ \\
Curriculum Fidelity & & & & 1 \\
\hline
\end{tabular}




\section{Conclusion, Discussion \& Suggestions}

In the study, it was aimed to develop a scale that makes valid and reliable measurements to determine the curriculum implementation approaches of teachers. The EFA results for determining the validity of the assessment tool showed that the scale consisted of four dimensions: "curriculum fidelity", "exam-based adaptation", "student-based adaptation" and "curriculum design". As a result of the analyzes conducted to determine the reliability of the scale, it was seen that the Cronbach alpha coefficients calculated for each factor ranged from 0.82 to 0.90 . It is accepted that the scale is reliable when the Cronbach alpha coefficient is 0.70 and above (Durmuş, Yurtkoru, \& Çinko, 2011). Analyzes for the item-total correlation and subscales correlation of the scale on the basis of subscales also show that the scale meets the reliability conditions.

In naming the sub-dimensions of the scale, the literature on curriculum implementation approaches (Ben-Peretz, 1990; Bümen, Çakar, \& Yıldız, 2014; Çeliker-Ercan, 2019; Çobanoğlu, 2011; Drake \& Sherin, 2006; Dusenbury, Brannigan, Falco, \& Hansen, 2003; Kabaoğlu, 2015; Kaya, Çetin, \& Yıldırım, 2012; Shawer, Gilmore \& Banks-Joseph, 2008; Snyder, Bolin \& Zumwalt, 1992; Tokgöz, 2013) and qualitative research findings made by the researcher prior to the writing of the scale items were used. As a result of EFA, it is seen that each item theoretically takes place under its own factor and the resulting factor structure is in accordance with the theory related to the subject. In this study, the curriculum implementation approaches of the teachers were determined by considering their commitment to the curriculum. Commitment to the curriculum is the implementation of the curriculum designed by experts, remaining faithful to the original (Bümen, Çakar, \& Yıldız, 2014). Within the scope of the research, the concept of commitment to the curriculum was handled as commitment to the curriculum materials (textbook, teacher's guidebook and student workbook) prepared in line with the official curriculum. When curriculum materials are mentioned, textbooks usually come to mind, but textbooks constitute only one element of curriculum materials (Ben-Peretz, 1990). Textbooks, which form a component of the curriculum, have an important place in determining the curriculum implementation approaches of teachers (Shawer, 2010). Textbooks define the official curriculum as they determine which subjects will be taught in what order and the time to be devoted to each subject (Freeman \& Porter, 1989; Yıldırım, 2006) and therefore represent the official curriculum (Elliott, 1990). Textbooks are prepared and distributed in line with the official curriculum. Moreover, within the scope of the curriculum developed with a centralized approach in Turkey, the textbooks prepared by the Ministry of National Education are distributed to all students and teachers are expected to use only these books. For this reason, teachers who adopt the approach of curriculum fidelity apply the content and activities in these books one-to-one and do not include any other resources or activities, while teachers who adapt the curriculum tend to make changes in the content and activities in these books or to use additional resources and activities in line with the interests, needs and expectations of the students. Thus, while determining the curriculum implementation approaches of the teachers, it will be useful to examine how teachers include the textbooks prepared by the Ministry of National Education in their classrooms, apart from whether they behave in accordance with the philosophy of the curriculum.

Within the scope of this research, when the items with the highest factor loading under each dimension of the scale are examined, it is seen that each dimension is in accordance with the theoretical framework. While the dimension of curriculum fidelity includes statements that teachers carry out their practices in the classroom by adhering to the English curriculum and curriculum materials without making any changes; In the dimensions of student-based and exam-based adaptation approaches, there are statements indicating that teachers take curriculum materials into account while implementing the curriculum in their classroom, but they also make adaptations in these materials focused on student characteristics or exam success. Finally, in the dimension of curriculum design, there are statements indicating that teachers' in-class practices differ from the official curriculum and that they do not use curriculum materials during their teaching. The naming as "curriculum design" is made to emphasize that the official curriculum and the curriculum materials provided by MNE are not used. In fact, the design process here mostly belongs to the teaching process. In other words, under the approach of curriculum design, the teacher does not create a curriculum design, but with the flexibility given to him 
by the private institution he works for, he can design his teaching-learning processes in the classroom in a very different way from it is stated in the official curriculum.

For the expressions in the scale under four dimensions, a 5-point Likert-type ranking was used as (1) Never, (2) Rarely, (3) Sometimes, (4) Frequently, (5) Always. Items 1, 2, 8 and 29 in the scale are reverse scored. Although a total score cannot be obtained from the entire scale, the scores obtained from the subscales show the level of teachers' having the approach expressed in the sub-scale. While the minimum score that teachers can get from the curriculum fidelity subscale is 6 , the highest score is 30 . While the minimum score they can get from the student-based adaptation subscale is 12 , the highest score is 60 . While the minimum score they can get from the exam-based adaptation subscale is 10 , the highest score is 50 . Finally, while the minimum score that teachers can get from the curriculum design subscale is 9 , the highest score is 45 . The increase in the scores obtained from the sub-scales indicates that the tendency of teachers towards the said approach also increases.

The results of the validity and reliability analyzes of the scale show that a scale has been developed that produces valid and reliable measurements that help determine the curriculum implementation approaches of secondary school English teachers. It is thought that this developed scale will primarily contribute to the literature on the implementation of the curriculum, and with the help of this scale, the curriculum implementation approaches of the teachers will be determined in large groups and will pave the way for further research on the effects of these approaches on teachers, students and schools. The application of this scale with English teachers who teach in different city and classroom levels will contribute to the validity and reliability of the scale. In addition, the application of the scale items by adapting them to different subject areas will guide the researches on the curriculum implementation approaches of the teachers in different courses. Confirmatory factor analysis could not be performed in this study due to the limited number of participants. For this reason, examining the test-retest reliability by performing confirmatory factor analysis in further studies is considered important in strengthening the data for the validity and reliability of the scale.

All rules included in the "Directive for Scientific Research and Publication Ethics in Higher Education Institutions" have been adhered to, and none of the "Actions Contrary to Scientific Research and Publication Ethics" included in the second section of the Directive have been implemented. 


\section{Türkçe Sürümü}

\section{Giriş}

Türkiye'de eğitim programları Millî Eğitim Bakanlığı (MEB) bünyesindeki Talim ve Terbiye Kurulu Başkanlığınca hazırlanıp merkeziyetçi bir yaklaşımla tüm ülkede uygulanmaktadır. Merkezde hazırlanan programlar ne kadar kaliteli olursa olsun, öğretmenler kendi sınıflarındaki öğrenciler için en iyi öğrenme yaşantılarını kendi bilgi, beceri, tutum ve davranışları ile çok daha iyi tespit edebilmektedir (Doll, 1970). Geçmişten günümüze yapılan çalışmalar da sınıfta uygulanan programların çoğunlukla öğretmenlerin kendi tutum, inanç, tercih, algı ve yeterlilikleriyle şekillendiğini göstermektedir (Ben-Peretz, 1990; Bümen, Çakar ve Yıldız, 2014; Meidl ve Meidl, 2011). Öğretmenlerin programları sınıfta uygularken kendi fikir ve yeterliliklerini programdaki temel fikirlerin yerine koymaları, öğretmen çeşitliliği kadar uygulanan programlarda da çeşitliliğine neden olmaktadır (Gökçek, 2008). Bu nedenle öğretmenlerin programla ilgili gerçek düşüncelerini ve düşüncelerinin sınıftaki uygulamalarına ne şekilde yansıdığını tespit etmeye ihtiyaç vardır (Akpınar, 2011).

Eğitim programları merkezde uzman kişiler tarafından hazırlanmasına rağmen, yapılan çalışmalarda programların beklenen derecede etkili olmadıkları çoğu zaman dile getirilmektedir. Bu durumun sebebini anlamak için programın uygulanmasını daha detaylı incelemek gerekmektedir. Öğretmenin program uygulama yaklaşımını incelemeden ve program uygulama düzeyini tespit etmeden program materyalleri ve öğrenme ürünleri ile ilgili bir değerlendirme yapmak doğru değildir (Fullan ve Pomfret, 1977). Bir öğretim programı ne kadar eksiksiz ve kusursuz hazırlanmış olursa olsun programın uygulayıcısı olan öğretmenler, program felsefesini ve temel aldığı anlayışları kavramadığı sürece programı etkili uygulayamazlar (Şeker, 2007). Dahası, öğrenci ilgi, ihtiyaç ve özelliklerinde var olan yerel farklılıklar programın her okulda ve her sınıfta planlandığı gibi uygulanması konusunda sıkıntılar yaratmaktadır (Bümen, Çakar ve Yıldız, 2014). Bu nedenle programın uygulayıcıları olan öğretmenler merkeziyetçi bir anlayışla hazırlanan öğretim programlarını sınıflarında uygularken planlanan halinden daha farklı bir şekle dönüştürebilmektedirler. Bu durum da Posner'ın tanımladığı program türlerinden "uygulamadaki program" kavramını ortaya çıkarmaktadır. Resmi program önceden hazırlanmış olsa da öğretmen ve öğrencilerin programla iletişimi gerçek programı yani diğer bir deyişle uygulamadaki programı oluşturmaktadır (Shawer, Gilmore ve Banks-Joseph, 2009). Uygulamadaki program, uzmanlar tarafından tasarlanan resmi programın sınıfta hayat bulmuş hali olarak tanımlanabilir. Tek bir program uygulanmasına rağmen bazı sınıflardaki öğrencilerin diğer sınıflara göre daha iyi öğrenmeleri her zaman merak konusu olmuştur. Dahası, tek bir programın uygulanması sonucu nasıl farklı programların ortaya çıktığını anlamaya ihtiyacımız vardır (Shawer, 2010). Bu noktada, resmi programı uygulamada farklı bir şekle dönüştürmede etkisi olan program uygulama yaklaşımları karşımıza çıkmaktadır.

Program uygulama yaklaşımları ile ilgili literatür incelendiğinde, öğretmenlerin ya programa bağlı kaldıkları ya da programda uyarlamalar yaptıkları görülmektedir (Ben-Peretz, 1990). Öğretim programına bağııık yaklaşımını benimseyen araştırmacılar, program geliştirme uzmanları tarafından geliştirilen öğretim programının sınıf içinde tam olarak uygulanmasına odaklanmaktadırlar. Uyarlama yaklaşımını benimseyenler ise, öğretim programı değişikliklerinin okullara yansıtılabileceğini, ancak programların okula uygun şekilde uyarlanması gerektiğini belirtmektedirler (Bümen, Çakar ve Yıldız, 2014). Programa bağııık ve programın uyarlanması yaklaşımlarına Synder, Bolin ve Zumwalt (1992) tarafından programın uygulanmasında öğretmenin iradesine vurgu yapan (enactment) üçüncü bir yaklaşım eklenmiştir. Bu üçüncü yaklaşıma göre, öğretmenler programda önemli değişiklikler yapan program geliştirme uzmanları gibi hareket ederler ve öğrenci deneyimlerinden yola çıkarak programı oluştururlar. Program artık öğretmen ve öğrenci deneyimlerinden oluşan bir üründür. Shawer (2003) da yabancı dil olarak İngilizce öğretimi yapan öğretmenler üzerinde gerçekleştirdiği çalışması sonucunda öğretmenlerin programa; programı aktaran (curriculum transmitters), programı geliştiren (curriculum developers) ve programı oluşturan (curriculum makers) gibi farklı şekillerde yaklaştığını belirtmiştir (Akt. Shawer, Gilmore ve 
Banks-Joseph, 2008). Buna göre programı aktaran öğretmenler, programın uygulanmasında bire bir program materyallerine bağlı kalırken, programı geliştirenler öğrenci ilgi, istek ve ihtiyaçları doğrultusunda program materyallerinde atlama, çıkarma, ek kaynak ve etkinlik sağlama gibi uyarlamalar yapabilmektedirler. Programı oluşturanlar ise öğrenci deneyimleri ile kendi tutum, inanç ve tecrübelerinden yola çıkarak sınıfta yapılacak uygulamaları belirleyebilmektedirler.

Snyder, Bolin ve Zumwalt (1992) öğretmenlerin programın uygulanmasında, programın aslına uygunluk (fidelity), karşılıklı uyum (adaptation) ve irade (enact) olmak üzere üç farklı program yaklaşımı benimsediklerini belirterek her bir yaklaşıma ait öğretmen davranışlarını tanımlamışlardır. Programın uygulanmasında aslına uygunluk yaklaşımını benimseyen öğretmenler, program materyallerini sadece temin eden aktarıcılardır. Bu öğretmenler geliştirilen programda yer alan amaçları ve içeriği olduğu gibi öğrencilere aktarırlar. Öğretmenler öğretimde öğrenci ders kitabını ve öğretmen kılavuz kitabını takip ederler. Öğrenci ders kitabı ve öğretmen kılavuz kitabı dışında yeni materyal ya da içerik sunmazlar. Ders kitabı içeriğini ünite ünite, ders ders, sayfa sayfa aktarırlar. Sınıf dinamiklerine cevap vermeden yalnızca içeriğe odaklanırlar ve eksik unsurları nadiren tamamlarlar. Öğretimde ders kitabı ya da öğretmen kılavuz kitabındaki etkinliklere sadık kalırlar. Ders kitabına bağlı bir öğretim gerçekleştirdikleri için genelde bir sonraki derste ne öğretileceği ve nasıl öğretileceği bellidir. Bu öğretmenlerin sınıflarında öğrenme sadece sınavı ya da dersi geçmeye yöneliktir. Karşılıklı uyum yaklaşımını benimseyen öğretmenler program düzenlemeleri yapan program uyarlayııılarıdır. Öğretmenler programdaki düzenlemelerle programın uygulanmasında daha aktif bir role sahiptir. Ders kitabındaki bazı bölümleri atlarlar, ders kitabında olmayan konular eklerler, program kapsamı dışındaki materyalleri/etkinlikleri sınıfa getirirler. Kısacası, öğretmenler program materyallerine ek olarak çeşitli kaynaklar kullanan program geliştiriciler olurlar. Öğrenci deneyimleri öğretimde önemli kaynaklardır. İrade yaklaşımını benimseyen öğretmenler program hakkında karar veren ve programda önemli değişiklikler yapan programcılar gibi hareket ederler. Bu yaklaşımda program öğretmen ve öğrenciler tarafından ortaklaşa oluşturulur. Program bilgisi daha önceki yaklaşımlarda olduğu gibi artık bir ürün değil, öğretmen ve öğrenciler tarafından oluşturulan deneyimlerden oluşan yapılardır. Bu yaklaşımda öğretmenler çoğunlukla basılı öğretim programı materyallerine başvurmadan öğretimi planlarlar.

Türkiye'de programın uygulanması ile ilgili yapılan çalışmalar incelendiğinde, doğrudan öğretmenlerin program uygulama yaklaşımlarını belirlemeye yönelik bir araştırmaya rastlanmamaktadır. Bununla birlikte, Tokgöz (2013) tarafından doktora tez çalışması kapsamında programın uygulanmasında öğretmenlerin benzerlik ve farklılık gösteren özelliklerinden yola çıkarak üç farklı öğretmen profili belirlenmiş ve bu profiller program takipçileri (curriculum followers), program genişleticileri (curriculum extenders) ve program uyarlayıcıları (curriculum adapters) olarak adlandırılmıştır. Bu sınıflamaya göre programı takip edenler, programın uygulanmasında, literatürde yer alan diğer sınıflamalardaki gibi program materyallerine bağlı kalırken, programı uyarlayanlar program materyallerindeki eksiklikleri başka kaynaklarla ya da kendi deneyimleri ile telafi edebilmektedirler. Bu sınıflamada yer alan programı genişletenler ise öğrenci başarısı özerine odaklanmakta ve bu nedenle programı sınıflarında uygularken, öğrencilerin ulusal sınavlardaki başarısını arttırmak ve sınav performansını yükseltmek amaçlı bilgi aktarımına öncelik vermektedirler. Diğer taraftan yurt dışındaki literatürde öğretmenlerin program uygulama yaklaşımlarının belirlenmesi ve bu yaklaşımların öğretmen ve öğrenci üzerindeki etkilerinin incelenmesi üzerine doğrudan araştırmalara rastlanırken (Shawer, 2010; Shawer, Gilmore ve BanksJoseph, 2008; 2009; Snyder, Bolin ve Zumwalt, 1992), Türkiye'de programın uygulanmasına yönelik literatürün, genellikle yenilenen öğretim programlarında benimsenen yapılandırmacı etkinliklerin uygulanma düzeyi, öğretmenlerin programın uygulanması ile ilgili görüşlerinin ve yaşadıkları sorunların belirlemesi ile kıııtlı olduğu dikkat çekmektedir (Adıgüzel, 2009; Aydemir, Aykaç ve Ulubey, 2012; Gürel ve Demirhan-isscan, 2020; Karacaoğlu ve Acar, 2010; Saraç ve Yıldırım, 2019; Tekbıyık ve Akdeniz, 2008; Yaşar, 2012). Bu araştırma kapsamında geliştirilen ölçeğin, özellikle Türkiye'de programın uygulanmasında öğretmen yaklaşımlarının büyük örneklem gruplarında belirlenmesi ve öğretmenlerin program uygulama yaklaşımlarının öğrenci, öğretmen ve okul üzerindeki etkilerinin incelenebilmesi gibi programın uygulanmasına yönelik ileri çalışmalara katkı sağlayacağı düşünülmektedir. Türkiye'de programın uygulanması üzerine literatürdeki bu eksiklikten yola çıkarak, bu çalışmada İngilizce 
öğretmenlerinin ilgili öğretim programını sınıflarında uygularken benimsedikleri program uygulama yaklaşımlarını belirlemeye yardımcı geçerli ve güvenilir ölçümler üreten bir ölçme aracının geliştirilmesi amaçlanmıştır.

\section{Yöntem}

\section{Araştırma Modeli}

Araştırma bir ölçek geliştirme çalışmasıdır. Ölçek geliştirme sürecinde öğretmenlerin program uygulama yaklaşımlarına ilişkin literatür taranarak ölçek maddeleri belirlenmiş, bu maddeler uzman görüşüne sunulduktan sonra aday ölçek oluşturulmuştur. Aday ölçeğin uygun örneklem üzerinde deneme uygulaması yapılarak faktör analizi gerçekleştirilmiş ve deneysel form elde edilmiştir. Bu doğrultuda bu çalışma deneysel süreç benimsenerek tasarlanmıştır (Yurdugül, 2012).

\section{Çalışma Grubu}

Öğretmenlerin program uygulama yaklaşımlarının belirlenebilmesi için bu çalışma yedinci sınıf Ingilizce öğretim programı ile sınırlandırılmışır. Böylece tüm öğretmenlerin aynı öğretim programını düşünerek ölçek maddelerini yanıtlaması hedeflenmiştir. Yedinci sınıf öğretim programının tercih edilmesinin nedeni ise, yedinci sınıflarda yapılan öğretimin, sekizinci sınıfta yapılan öğretime kıyasla daha az sınav odaklı olmasıdır. Böylece öğretmenlerin ölçek maddelerindeki ifadeleri sınav baskısı altında olmadan, genel olarak yaptıkları uygulamaları dikkate alarak derecelendirmeleri amaçlanmıştır.

Araştırma ortaokul yedinci sınıfta öğretim yapan İngilizce öğretmenleri ile sınırlandırıldığından ulaşılacak öğretmen sayısı da sınırlı hale gelmiştir. Ölçekteki maddelerin geçerlik ve güvenirlik çalışmalarının sağıklı bir şekilde gerçekleştirilebilmesi için ise belli sayıda öğretmene ulaşmak gerekmektedir. Dolayısıyla veri toplamada kolaylık sağlamak amacıyla kolayda örnekleme yöntemi ile tüm öğretmenlere ulaşılmaya çalışılmıştır. Bu kapsamda Eskişehir ilinin Tepebaşı ve Odunpazarı merkez ilçelerinde bulunan $57^{\prime}$ si devlet okulu, 9'u özel okul olmak üzere toplam 66 ortaokula gidilmiş ve bu okullarda yedinci sınıflarda öğretim yapan ve araştırmaya katılmaya gönüllü olan 181 İngilizce öğretmeni araştırmaya dahil edilmiştir. Çalışma grubunu oluşturan öğretmenlerin 153'ü $(\% 84,5)$ kadın, $28^{\prime} i(\% 15,5)$ erkektir ve bu öğretmenlerden 162'si $(\% 89,5)$ devlet okulunda, 19'u $(\% 10,5)$ ise özel okullarda görev yapmaktadır.

\section{Verilerin Toplanmasından Önce Yapılan İşlemler}

Araştırma kapsamında ortaokul ingilizce öğretmenlerinin program uygulama yaklaşımlarını belirlemek amacıyla ölçek maddelerinin oluşturulmasında, hem öğretmenlerin program uygulama yaklaşımları ile ilgili literatürden (Ben-Peretz, 1990; Bümen, Çakar ve Yıldız, 2014; Çeliker-Ercan, 2019; Çobanoğlu, 2011; Drake ve Sherin, 2006; Dusenbury, Brannigan, Falco, Hansen, 2003; Kabaoğlu, 2015; Kaya, Çetin ve Yıldırım, 2012; Shawer, Gilmore ve Banks-Joseph, 2008; Snyder, Bolin ve Zumwalt, 1992; Tokgöz, 2013), hem mevcut İngilizce dersi öğretim programının özelliklerinden, hem de araştırmacı tarafından ölçek geliştirme çalışmasına başlamadan önce öğretmenlerin program uygulama yaklaşımlarını belirlemeye yönelik sınıflarda gerçekleştirdiği uzun süreli gözlem ve görüşmelerden elde edilen nitel verilerden faydalanılmıştır.

Öğretmenlerin program uygulama yaklaşımları ilgili literatür ağırıklı olarak yurt dışı çalışmalarda ele alınmaktadır ve Türkiye'de bu konuda yapılan çalışmalar oldukça kısıtıdır. Bu nedenle ölçeğin uygulanacağı grupta öğretmenlerin program uygulama yaklaşımlarının yurt dışındaki literatürden farklılıklar gösterebileceği varsayımı ile ölçek maddelerinin yazımı öncesinde böyle bir nitel çalışmaya ihtiyaç duyulmuştur. Bu doğrultuda maksimum çeşitlilik örnekleme tekniği ile Eskişehir ilinin Tepebaşı ve Odunpazarı ilçelerinde bulunan düşük, orta, yüksek başarı düzeyindeki ortaokullarda ve ayrıca özel okullarda çalışan toplam 14 ingilizce öğretmeni ile nitel bir çalışma yürütülmüştür. Bu çalışmada uzun süreli gözlem, öğretmen ve öğrenci görüşmeleri yolu ile öğretmenlerin ortaokul yedinci sınıf İngilizce dersi öğretim programını sınıflarında nasıl uyguladıkları incelenerek program uygulama yaklaşımları belirlenmeye çalışılmışır. Elde edilen verilerin analizi sonucunda çalışma grubundaki öğretmenlerin, programa bağılık, programı uyarlama ve programı tasarlama olmak üzere üç farklı yaklaşıma sahip 
oldukları görülmüştür. Her bir yaklaşımda öğretmen uygulamalarının öğrenci odaklı ve sınav odaklı olmak üzere ikiye ayrıldığı görülmüş, özellikle uyarlama yaklaşımında bu odak noktaları daha net bir şekilde ortaya çıkmıştır. Her bir yaklaşıma sahip öğretmen özellikleri aşağıda kısaca açıklanmışırı.

Programa bağlıık yaklaşımını sergileyen öğretmenler, sınıfta yaptığı uygulamalarda uzmanlarca tasarlanan İngilizce dersi öğretim programına ve söz konusu program kapsamında hazırlanan ders kitaplarına sadık kalmaktadır. Bu öğretmenler derslerinde sadece MEB kaynaklarına yer vererek bu kaynaklardaki etkinlikleri hiçbir uyarlama yapmadan olduğu gibi uygulamaktadırlar. Bunun yanı sıra, programın önerdiği şekilde, ders kitaplarındaki dinleme ve konuşma gibi iletişim odaklı etkinliklere de mutlaka yer vermekte ve değerlendirme süreçlerinde süreç değerlendirmeyi de dikkate almaktadırlar. Diğer taraftan bu öğretmenler programa ve MEB kaynaklarına bağlı kaldıkları için sadece MEB kaynaklarındaki kazanım, içerik ve etkinliklerin uygulanmasını önemseyerek öğrenci ilgi ve isteklerini göz ardı etmektedirler.

Programın uyarlanması yaklaşımına sahip öğretmenler, ilgili öğretim programı ve program kapsamında hazırlanan ders kitaplarındaki kazanımlar, içerik, etkinlikler vb. üzerinde sınıftaki uygulamalar esnasında değişiklik yapmaktadır. Öğretmenler bu değişiklikleri bazen öğrenci ilgi, istek ve ihtiyaçlarını karşılamak üzere öğrenci özellikleri doğrultusunda gerçekleştirirken, bazen de sistemin öğretmene yüklediği sorumluluklar nedeniyle sınava hazırlamaya yönelik gerçekleştirmektedirler. Bu nedenle öğrenci odaklı ve sınav odaklı uygulamaların en çok farklılaşığı uygulamalar programın uyarlanması yaklaşımında yer almaktadır. Öğrenci odaklı uyarlama yaklaşımına sahip öğretmenler sınıflarında MEB kaynakların kullanmakla birlikte bu kaynaklardaki etkinliklerde öğrenci ilgi, intiyaç ve istekleri doğrultusunda değişiklikler yapmaktadırlar. Bu öğretmenler, kitaptaki etkinlik öğrenci seviyesine uygun olmadığında etkinliği atlayabilmekte, basitleştirebilmekte ya da kendi getirdiği başka bir etkinlikle değiştirebilmektedir. Ayrıca bu öğretmenler öğrenci ilgisini çekmek ve derse olan motivasyonu arttırmak amacıyla ders kitabındaki etkinlikler dışında sınıfa materyal ve etkinlik getirmektedirler. Kısacası bu öğretmenler söz konusu öğretim programında ve ders kitaplarında öğrenci özelliklerini dikkate alarak değişiklikler yapmaktadırlar. Sınav odaklı uyarlama yaklaşımına sahip öğretmenlerin yaptıkları değişimin temel amacı öğrencileri sınava hazırlamaktır. Bu yaklaşımı benimseyen öğretmenler merkezi sınavlarda, ilgili program ve ders kitapları dikkate alınacağından, bu kitaplardaki içeriğin ve kazanımların olduğu gibi tüm ayrıntılarıyla verilmesini önemserken, sınavda ölçülmediği için dinleme ve konuşma gibi iletişim becerilerine yönelik etkinlikleri göz ardı etmektedirler. Bu nedenle genellikle ders kitabındaki bu etkinlikleri atlamakta ya da sadece bu etkinliklerde geçen dil bilgisi kalıplarına ve kelimelere odaklanarak etkinliğin iletişimsel amacını yok saymaktadırlar. Söz konusu programda ingilizce'nin bir ders olarak öğretilmemesi, bir iletişim aracı olarak görülmesi vurgulanmaktadır. Fakat bu öğretmenler derslerinde öğrencileri sınava hazırlamaya yönelik olarak ayrıntılı dilbilgisi konu anlatımına yer vererek İngilizce'yi ezberlenmesi gereken bir ders olarak görmektedirler. Öğrencilerin yanlışlarına tahammülleri olmadığı için genellikle hataları anında düzeltmektedirler. Yine programda belirtilenin aksine, derslerinde konu anlatımına daha fazla odaklandıklarından, sınıflarında ağırıklı olarak Türkçe kullanımına yer vermektedirler.

Programın tasarlanması yaklaşımını benimseyen öğretmenler sınıfta yaptığı uygulamalarda ilgili öğretim programına ya da program kapsamında hazırlanan ders kitaplarına başvurmamaktadırlar. Çalıştıkları kurumun (özel okul) program uygulama politikasına da bağlı olarak bu öğretmenler derslerinde genellikle başka bir kaynak kullanmaktadırlar. Derste yer verdikleri kazanım ve temalar MEB materyallerinde belirtilenden farklıdır. Bu öğretmenler genellikle derste yaptırdığı etkinlikleri öğrenci ilgi istek ve ihtiyaçları doğrultusunda şekillendirmekte ve öğrenciye seçme hakkı tanımaktadırlar.

Taslak maddelerin oluşturulmasında, araştırmacı tarafından önceden gerçekleştirilen nitel çalışmanın verileri de dikkate alınarak, öğretimin planlanmasına, kullanılan kaynaklara ve program öğelerine (hedef, içerik, eğitim durumları ve sınama durumları) yönelik ifadelere yer verilmiştir. Ölçek için oluşturulan taslak maddeler (62 madde), kapsam geçerliği açııından eğitim bilimleri alanında çalışmaları bulunan beş uzmana sunulmuştur. Maddelerin çalışılan konuyu temsil etme düzeyi ve açıklığı ile ilgili alınan uzman görüşleri doğrultusunda, ölçülmek istenen konu ile alakasız olan ya da gereksiz olduğu düşünülen 
maddeler ( 7 madde) taslak ölçek formundan çıkarılmış ve yine anlaşılır olmayan bazı maddelerde ifadeler daha anlaşılır olacak şekilde yeniden yazılmıştır. Uzman görüşü sonrasında, taslak ölçek formu ortaokul yedinci sınıflarda öğretim yapan beş ayrı İngilizce öğretmenine gönderilerek, maddelerin açıklığı ve uygunluğuna ilişkin görüş alınmıştır. Son olarak dil ve anlaşılırlık açısından taslak ölçek formu Türkçe eğitimi alanında iki ayrı uzmana gönderilmiştir. İngilizce öğretmenlerinden ve uzmanlardan gelen geri bildirimler doğrultusunda, taslak ölçek maddelerindeki yazım yanlışları düzeltilmiş ve öğretmenler tarafından anlaşılmayan bazı ifadeler öneriler dikkate alınarak yeniden yazılmıştır. Ölçek maddelerinde yapılan düzeltmelerden sonra, 5'li Likert türü ölçekteki her bir ifade (1) Asla, (2) Nadiren, (3) Bazen, (4) Sıklıkla, (5) Her zaman olacak şekilde derecelendirilmiştir. Nihayetinde, 55 maddelik nihai form oluşturulmuş ve ölçeğin uygulama aşamasına geçilmiştir.

\section{Verilerin Toplanması ve Analizi}

Bu çalışmada 55 maddeden oluşan nihai ölçek formu ortaokul yedinci sınıflarda öğretim yapan 181 İngilizce öğretmenine uygulanmıştır. Uygulama sürecinde araştırmacı okullara giderek ölçeği öğretmenlere vermiş ve konu ile ilgili bilgilendirme yaparak ölçeği uygun bir şekilde yanıtlamalarını istemiştir. Araştırma verilerinin toplanması, 2018-2019 eğitim-öğretim yılı Kasım-Aralık aylarında iki ay sürmüştür ve ölçeğin yanıtlanma süresi 15-20 dakikadır. Ölçek geliştirme sürecinde, geçerli ve güvenilir ölçümler üreten bir ölçme aracı elde edebilmek için geliştirilen ölçeğin geçerlik ve güvenirlik çalışmalarının yapılması önemlidir. Bu araştırma kapsamında geliştirilen ölçeğin geçerliği içerik (kapsam) geçerliği ve yapı geçerliği analizleri; güvenirliği ise iç tutarlılık yöntemleri ile sağlanmaya çalışılmıştır.

\section{Bulgular}

\section{Ölçeğin Geçerliğine İlişkin Bulgular}

Bu çalışma kapsamında geliştirilen ölçeğin geçerliği kapsam ve yapı geçerliği aracılığıyla incelenmiştir. Kapsam geçerliliği ile ilgili yapılan çalışmalara verilerin toplanmasından önce yapılan işlemler kısmında değinilmiştir. Bu nedenle bu bölümde ölçeğin uygulanması sonrasında yapı geçerliğine ilişkin yapılan çalışmalara yer verilmiştir.

Bu araştırma kapsamında geliştirilen ölçeğin yapı geçerliğini incelemek için açımlayıcı faktör analizi (AFA) yapılmıştır. AFA uygulamasından önce, veri setinin faktör analizine uygunluğunu belirlemek için, kayıp değerler, örneklem büyüklüğü, homojenlik, normallik ve doğrusallık gibi gerekli sayıltılar incelenmiştir. Öncelikle kayıp değerler içeren maddelere ortalama değerler atanarak veri seti analize hazır hale getirilmiştir. Örneklem büyüklüğünün faktörleştirmeye uygunluğunu test etmek için ise Kaiser Meyer Olkin (KMO) ve Barlett testi sonuçları dikkate alınmıştır. AFA sonucunda elde edilen KMO=0.817, $\mathrm{X}^{2}=5353.073, s d=1485$ ve Bartlett $(p=.000<0.01)$ değerleri AFA yapılabilmesi için örneklemin yeterli olduğunu göstermiştir. Verilerin homojenliğinin test edilmesinde ise Levene test sonuçlarından faydalanılmıştır. Levene test sonuçları veri setindeki bağımlı değişkenlerin bağımsız değişken gruplarında eşit varyansa sahip olduğunu, yani homojen olduğunu göstermiştir ( $p>0.05)$. Normal dağılımın incelenmesinde ise basıklık/çarpıklık değerleri dikkate alınmıştır. Genellikle \pm 1.0 arasındaki basıklık değerleri mükemmel kabul edilmekle birlikte, çoğu durumlarda \pm 2.0 arasındaki değerler de kabul edilmektedir (George ve Mallery, 2016). Bununla birlikte basıklık değeri \pm 3.0 aralığında olan değişkenlerin de tipik bir normal dağılımdan geldiği ifade edilmektedir (Kalaycı, 2010). Bu çalışma kapsamında elde edilen verilerin basıklık/çarpıklık değerleri kabul edilebilir değerler arasında olduğundan veriler normal dağılım sayıltısını karşılamaktadır.

Ölçeğin faktör desenini belirlerken, faktörleştirme yöntemi olarak temel bileşenler analizi ve döndürme yöntemi olarak dik döndürme yöntemlerinden maksimum değişkenlik (varimax) kullanılmıştır. Faktör, kendi aralarında yüksek korelasyon gösteren maddelerin oluşturdukları kümeye verilen isimdir (Çokluk, Şekercioğlu ve Büyüköztürk, 2014). Yapılan ilk AFA sonucunda ölçekte yer alan ifadelerin, öz değeri 1'den yüksek 13 faktör altında anlamsız bir şekilde dağıldığı görülmüştür. Öz değerlere bakarak faktör sayısına karar vermek her zaman güvenilir sonuçlar vermeyebilir (Green ve Salkind, 2005). Bu nedenle faktör sayısının belirlenmesinde yamaç birikinti grafiği (scree plot) ile faktörlerin açıkladıkları ek varyansın yüzdesi dikkate alınmıştır. 
Faktörlerin, toplam varyansın açıklanmasına getirdiği katkı \%5'in altına düştüğünde bir önceki faktörün son faktör olduğu yönünde karar verilir (Can, 2013). Bu doğrultuda, dördüncü faktörden sonraki faktörlerin toplam varyansa yaptıkları katkının \%5'ten daha az olduğu görülmüştür. Yamaç birikinti grafiği ise öz değerleri grafiğe dönüştürerek her bir faktörün göreceli önemini daha belirgin hale getirir (Field, 2009). Yamaç birikinti grafiğinde çizgi eğiminin çarpıcı bir şekilde değiştiği kırılma noktası faktör sayısının belirlenmesinde kullanılmaktadır. Çizginin yatay bir şekil almaya başladığı son noktadan önceki noktalar arasında kalan çizgiler faktör sayısına işaret etmektedir. Bu doğrultuda Şekil 1'de verilen yamaç birikinti grafiği, ölçekte yer alan maddelerin 4 faktör altında toplandığını göstermektedir.

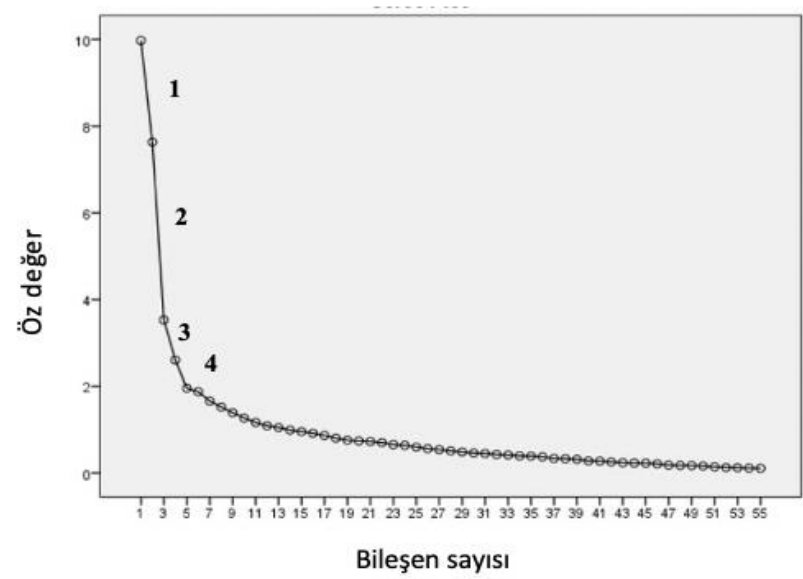

Şekil 1. Faktör sayısını gösteren yamaç birikinti grafiği

Yamaç birikinti grafiği ve faktörlerin toplam varyansa yaptıkları bireysel katkı dikkate alınarak faktör sayısı dört olarak belirlenmiştir. Faktör sayısının dört olarak belirlenmesi, ölçek maddelerinin yazımında belirlenen teorik yapıda beklenen sayı ile uyumlu olması bakımından da anlamlıdır. Bu nedenle AFA dört faktörlü olacak şekilde tekrarlanmıştır. Dört faktör için tekrarlanan analiz sonucunda, faktörlerin toplam varyansa yaptıkları katkının birinci faktör için \%15.64, ikinci faktör için \%13,54, üçüncü faktör için \%12,73 ve dördüncü faktör için \%8.72 olduğu görülmüştür. Bu dört faktörün ortak varyansa yaptıkları toplam katkı ise \%50.62'dir. AFA çalışmalarında faktörlerin toplam varyansı açıklama oranının alt sınırı \%40 olarak kabul edilmektedir (Kline, 1994, Akt., Karadağ, 2009). Bu nedenle alt faktörlerin açıkladığı toplam varyans değeri yeterlidir. Tablo 1'de ölçekte yer alan 4 faktörün başlangıçta ve döndürme sonrasında sahip oldukları öz değer ile açıkladıkları varyans miktarları verilmiştir.

Tablo 1.

Öğretmenlerin program uygulama yaklaşımları ölçeğinde yer alan faktörlerin öz değerleri ve varyans yüzdeleri

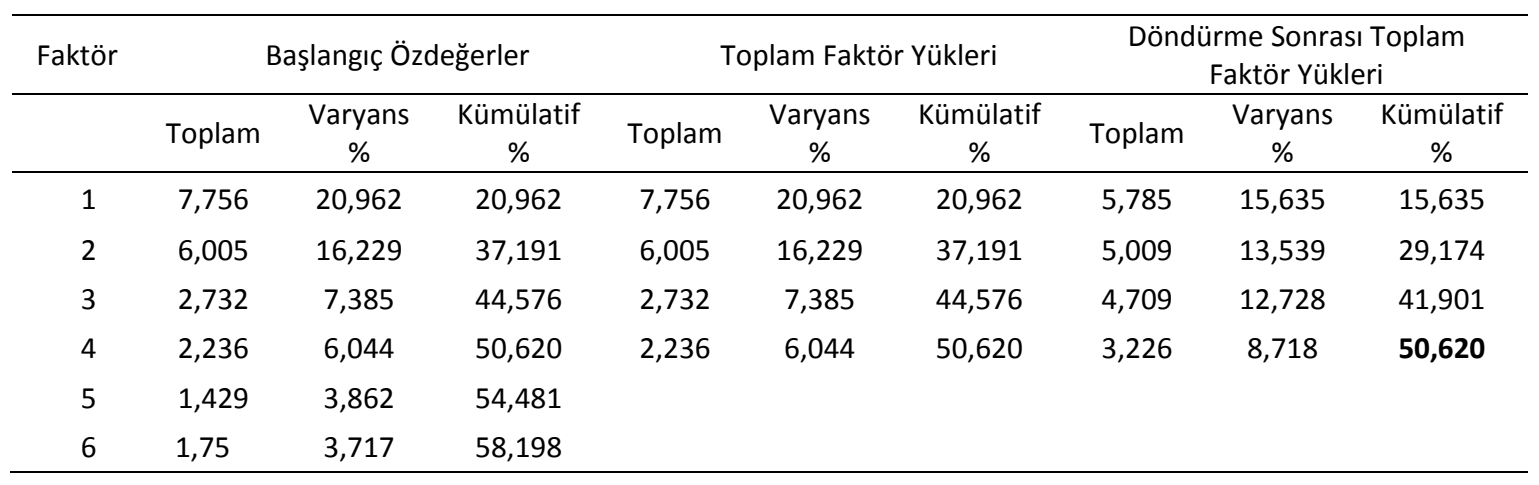


Bu çalışmada ölçekteki maddelerin faktör yük değerleri için kabul düzeyi 0.50 olarak belirlenmiştir. Faktör yük değeri maddelerin faktörlerle olan ilişkisini açıklayan bir katsayıdır ve maddelerin, ait oldukları faktörlerdeki yük değerlerinin yüksek olması beklenir (Kleine, 2014). Literatür incelendiğinde faktör yük değerinin en az 0.30 olması gerektiğine ilişkin yaygın bir görüş vardır. Bununla birlikte, faktör yük değerine karar verirken örneklem büyüklüğünü de dikkate almak gerekir (Field, 2009). Bu değerlere ilişkin pek çok görüş yer almakla birlikte, Kim-Yin (2004, Akt., Şencan, 2005), bir maddenin ölçekten çıkarılıp çıkarılmayacağına dair karar verirken belli örneklem büyüklükleri için dikkate alınması gereken faktör yük değerlerini şöyle açıklamıştır. Örneklem büyüklüğü an az 350 ise faktör yükü 0.30; örneklem büyüklüğü en az 200 ise faktör yükü 0.40; örneklem büyüklüğü en az 120 ise faktör yükü 0.50; örneklem büyüklüğü en az 85 ise faktör yükü 0.60 ve örneklem büyüklüğü en az 60 ise faktör yükü 0.70 olarak alınmalıdır. Bu çalışma kapsamında örneklem sayısı 181 olduğu için faktör yük değerinin 0.50 olarak belirlenmesi uygun görülmüştür. Yapılan analiz sonucunda, faktör yük değeri kabul düzeyini karşılamayan ve bu değeri karşıladığı halde binişiklik özelliği gösteren toplam 18 madde ölçekten çıkarılmıştır. Bu maddelerin analizden çıkarılması sonucunda 37 maddeden elde edilen faktör deseni, bu maddelerin faktör yük değerleri ve ortak faktör varyansları Tablo 2'de verilmiştir.

Tablo 2.

Öğretmenlerin program uygulama yaklaşımları ölçeğinin faktör deseni

\begin{tabular}{|c|c|c|c|c|c|c|}
\hline \multirow[b]{2}{*}{$\begin{array}{l}\text { Sira } \\
\text { No }\end{array}$} & \multirow[b]{2}{*}{$\begin{array}{c}\text { Madde } \\
\text { No }\end{array}$} & \multicolumn{4}{|c|}{ Alt Ölçekler } & \multirow{2}{*}{$\begin{array}{c}\text { Ortak } \\
\text { Faktör } \\
\text { Varyansı }\end{array}$} \\
\hline & & $\begin{array}{c}\text { Programın } \\
\text { Tasarlanması }\end{array}$ & $\begin{array}{l}\text { Öğrenci Odaklı } \\
\text { Uyarlama }\end{array}$ & $\begin{array}{l}\text { Sınav Odaklı } \\
\text { Uyarlama }\end{array}$ & $\begin{array}{l}\text { Programa } \\
\text { Bağlılık }\end{array}$ & \\
\hline & & Faktör Yükü & Faktör Yükü & Faktör Yükü & Faktör Yükü & \\
\hline 1 & 6 & ,796 & & & & 663 \\
\hline 2 & 11 & ,786 & & & & 667 \\
\hline 3 & 21 & 748 & & & & 653 \\
\hline 4 & 14 & ,732 & & & & ,660 \\
\hline 5 & 8 & 703 & & & & ,629 \\
\hline 6 & 2 & 694 & & & & ,576 \\
\hline 7 & 55 & ,676 & & & & ,470 \\
\hline 8 & 41 & ,669 & & & & ,511 \\
\hline 9 & 1 & ,557 & & & & 393 \\
\hline 10 & 38 & & 718 & & & ,533 \\
\hline 11 & 35 & & 691 & & & ,508 \\
\hline 12 & 34 & & ,689 & & & 492 \\
\hline 13 & 36 & & ,685 & & & ,501 \\
\hline 14 & 19 & & ,596 & & & ,572 \\
\hline 15 & 53 & &, 570 & & & ,357 \\
\hline 16 & 37 & & ,556 & & & 317 \\
\hline 17 & 9 & & ,552 & & & 347 \\
\hline 18 & 7 & & ,537 & & & ,334 \\
\hline 19 & 18 & & ,530 & & & ,409 \\
\hline 20 & 20 & & ,510 & & & 410 \\
\hline 21 & 13 & & ,507 & & & ,448 \\
\hline 24 & 23 & & & 689 & &, 520 \\
\hline 25 & 47 & & & 651 & & ,449 \\
\hline 26 & 39 & & & 631 & & ,440 \\
\hline 27 & 10 & & & 627 & & ,458 \\
\hline 28 & 54 & & & 608 & & ,410 \\
\hline 29 & 46 & & & 602 & & ,481 \\
\hline 30 & 5 & & & ,594 & & ,448 \\
\hline 31 & 48 & & & ,566 & & ,460 \\
\hline 32 & 26 & & & & 755 & 665, \\
\hline 33 & 24 & & & & 755 & 666, \\
\hline 34 & 45 & & & & 723 & 591 \\
\hline 35 & 25 & & & & 643, & 674, \\
\hline 36 & 29 & & & & 615, & 502 \\
\hline
\end{tabular}


Yapılan AFA sonucunda her maddenin teorik olarak kendi faktörü altında yer aldığı görülmüştür. Her bir faktörde yer alan maddeler incelenerek faktörler isimlendirilmiştir. Birinci faktör altında yer alan 9 maddenin faktör yükleri 0.56 ile 0.80 arasında değişmektedir. Bu faktör altında yer alan altıncı madde olan "Dersimi MEB kaynaklarından bağımsız planlarım” ifadesi en yüksek faktör yüküne sahiptir. Bu madde ile birlikte birinci faktör altında yer alan diğer maddeler incelendiğinde, bu maddelerin, öğretmenlerin sınıflarında gerçekleştirdikleri uygulamalarda MEB tarafından temin edilen ders kitaplarına bağlı kalmadıklarını, aksine MEB kaynaklarından tamamen farklı kaynakları dikkate alarak yaptıkları uygulamaları ifade ettiği görülmektedir. Bu nedenle birinci faktör "programın tasarlanması" olarak adlandırılmıştır. Buradaki tasarlama kavramı daha çok öğretmenin öğretim etkinliklerine yöneliktir. Yani öğretmen sınıftaki uygulamalarında program materyalleri kapsamında MEB materyallerine hiç yer vermeyerek tamamen farklı kaynaklar ve kendi deneyimleri doğrultusunda öğretimini şekillendirerek resmi öğretim programından farklı bir şekilde öğretimini tasarlamaktadır. İkinci faktör altında yer alan 12 maddenin faktör yükleri 0.51 ile 0.72 arasında değişmektedir. İkinci faktör altında yer alan otuz sekizinci madde olan "Dersimde, MEB kaynaklarındaki etkinlikler dışında, oyun oynama, video izleme, şarkı dinleme, yarışma gibi öğrencinin aktif olacağı ek etkinliklere yer veririm" ifadesi en yüksek faktör yüküne sahiptir. Bu madde ile birlikte ikinci faktör altında yer alan diğer maddeler incelendiğinde, bu maddelerin öğretmenlerin sınıflarında programı uygularken MEB tarafından temin edilen kaynakları kullandıkları, fakat bu kaynakları uygularken öğrenci profili doğrultusunda uyarlamalar yaptıkları yönünde ifadeler olduğu görülmektedir. Bu nedenle ikinci faktör "öğrenci odaklı uyarlama” olarak adlandırılmıştır. Üçüncü faktör altında yer alan 10 maddenin faktör yükleri 0.57 ile 0.71 arasında değişmektedir. Üçüncü faktör altında yer alan on altıncı madde olan "Kazanımlar içerisinden, merkezi sınavlarda ağırlıklı olarak ölçülen beceri alanlarına dersimde daha fazla yer veririm" ifadesi en yüksek faktör yüküne sahiptir. Bu madde ile birlikte üçüncü faktör altında yer alan diğer maddeler incelendiğinde, bu maddelerin, öğretmenlerin programı uygularken MEB tarafından temin edilen kaynakları kullandıklarını, fakat bu kaynakların uygulanmasında öğrencileri sınavlara hazırlamaya yönelik uyarlamalar yaptıklarını ifade ettiği görülmektedir. Bu nedenle üçüncü faktör "sınav odaklı uyarlama" olarak adlandırımıştır. Son faktör olan dördüncü faktörde ise faktör yükleri 0.51 ile 0.76 arasında değişen 6 madde yer almaktadır. Dördüncü faktör altında yer alan yirmi altıncı madde olan "Dersimde MEB kaynaklarındaki etkinlikleri, hiçbir değişiklik yapmadan, belirtildiği şekilde uygularım" ifadesi en yüksek faktör yüküne sahiptir. Bu madde ile birlikte dördüncü faktör altında yer alan diğer maddeler incelendiğinde, bu maddelerin, programın uygulanması sırasında öğretmenlerin MEB tarafından temin edilen kaynaklara sıkı sıkıya bağıı kaldıklarını ifade ettiği görülmektedir. Bu nedenle dördüncü faktör "programa bağlılık" olarak adlandırılmıştır. Her bir faktör altında yer alan maddeler ile birlikte ölçeğin düzenlenmiş son hali Ek-1'de verilmiştir.

\section{Ölçeğin Güvenirliğine İlişkin Bulgular}

Bu çalışmada geliştirilen ölçme aracının güvenirlik analizleri iç tutarlık güvenirliği kapsamında Cronbach Alfa değeri, madde-toplam korelasyonu ve alt ölçekler korelasyonu ile incelenmiştir. Cronbach alfa katsayısının 0.70 ve üstü olduğu durumlarda ölçeğin güvenilir olduğu kabul edilmektedir (Durmuş, Yurtkoru ve Çinko, 2011). Bu çalışma kapsamında geliştirilen ölçeğin alt boyutları için hesaplanan Cronbach Alfa katsayıları 0.82 ile 0.90 arasında değişmektedir. Tablo 3'te ölçeğin tüm alt faktörleri için hesaplanan Cronbach Alfa katsayıları verilmiştir.

Tablo 3.

Öğretmenlerin program uygulama yaklaşımları alt ölçeklerinin Cronbach alfa güvenirlik katsayıları

\begin{tabular}{cccc}
\hline & Faktörler & Madde Sayısı & Cronbach Alfa Katsayısı \\
\hline 1 & Programın Tasarlanması & 9 & .903 \\
2 & Öğrenci Odaklı Uyarlama & 12 & .861 \\
3 & Sınav Odaklı Uyarlama & 10 & .847 \\
4 & Programa Bağlılık & 6 & .821 \\
\hline
\end{tabular}


Madde-toplam korelasyon katsayısının 0.30'un altında ya da negatif olması, ilgili maddelerde bir sorun olduğuna işaret eder (Field, 2002, Akt., Şencan, 2005). Yapılan madde-toplam puan korelasyonu analizi sonucunda korelasyon katsayıları, "programın tasarlanması" alt boyutu için 0.55 ile 0.83 ; "öğrenci odaklı uyarlama" alt boyutu için 0.52 ile 0.74 ; "sınav odaklı uyarlama" alt boyutu için 0.57 ile 0.72 ve "programa bağlılık" alt boyutu için 0.62 ile 0.83 arasında, tüm maddeler için pozitif ve istatistiksel olarak anlamlı bulunmuştur $(p<0.01 ; p=0.00)$. Bu durum, ölçeğin alt boyutları kapsamında madde-toplam korelasyonu güvenirliğini sağladığını göstermektedir. Ölçeğin alt boyutlarında yer alan tüm maddelerin madde-toplam korelasyon katsayıları Tablo 4'te verilmiştir.

Tablo 4.

Öğretmenlerin program uygulama yaklaşımlarını belirleme ölçeğinin madde toplam korelasyonlarını belirlemek amacıyla yapılan pearson moment çarpım korelasyon analizi sonuçları*

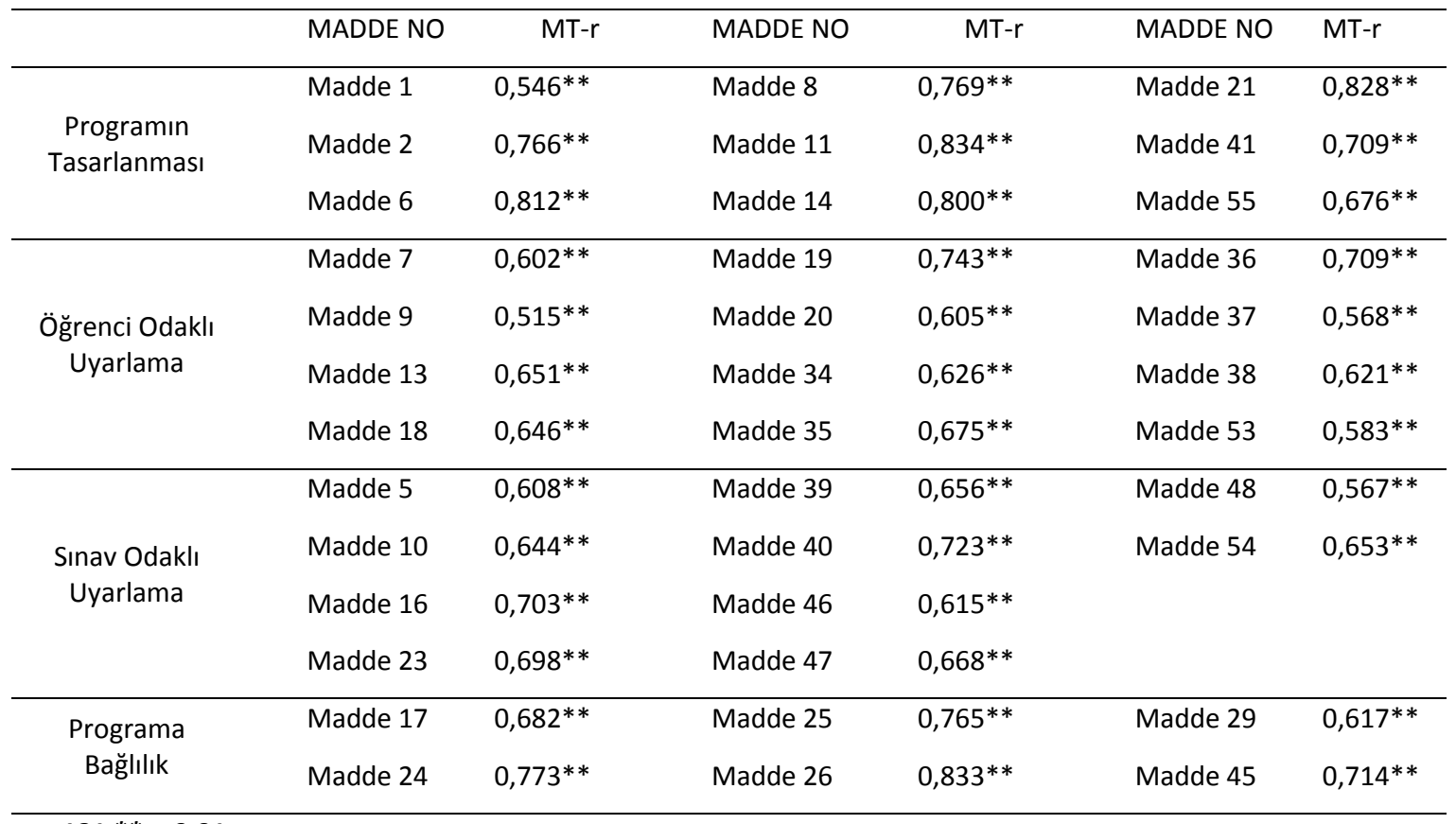

$n=181, * * p<0.01$

* Formun tamamından elde edilecek toplam bir puan olmadığından madde-toplam puan korelasyonları maddealt ölçek toplam puanı olarak hesaplanmıştır.

Alt ölçekler korelasyonu kapsamında ölçekte bulunan alt ölçekler arasındaki ilişkinin belirlenmesi için Pearson Moment çarpım korelasyon analizi yapılmıştır. Alt ölçek puanları arasındaki korelasyonlar -0.11 ile -0.47 arasında değişmektedir. Yapılan analiz sonucunda öğrenci odaklı uyarlama alt ölçeği ile programa bağlılık alt ölçeği arasındaki korelasyon hariç diğer tüm alt ölçeklerdeki korelasyonun istatistiksel olarak anlamlı olduğu görülmüştür $(p<0.01 ; p=0.00)$. Bu ölçekten toplam bir puan alınamamaktadır ve teorik olarak ölçekteki tüm faktörler arasında bir ilişki öngörülmemektedir. Ölçekte yer alan bazı faktörler arasında ilişki görülürken bazıları arasında hem teorik hem de veri temelinde ilişki olmamasından dolayı ölçek geliştirme sürecinde, ölçeğin faktör desenini belirlerken oblimin yerine dik döndürme yöntemlerinden varimax kullanılmıştır. Tablo 5 'te alt ölçeklerin birbiri ile olan korelasyon katsayıları verilmiştir. 
ÇELIKER ERCAN \& ÇUBUKÇU - Çukurova Üniversitesi Eğitim Fakültesi Dergisi, 50(2), 2021, 1464-1490

Tablo 5.

Öğretmenlerin program uygulama yaklaşımları ölçeğinin alt ölçekler korelasyonu için pearson moment çarpım korelasyon analizi sonuçları

\begin{tabular}{lllll}
\hline & Tasarlama & Öğrenci Odaklı & Sınav Odaklı & Bağııık \\
\hline Tasarlama & 1 & $0,36^{* *}$ & $-0,18^{*}$ & $-0,47^{* *}$ \\
Öğrenci Odaklı & & 1 & $0,21^{* *}$ & $-0,11$ \\
Sınav Odaklı & & & 1 & $0,23^{* *}$ \\
Bağlıık & & & 1 \\
\hline
\end{tabular}

\section{Sonuç, Tartışma ve Öneriler}

Araştırmada öğretmenlerin program uygulama yaklaşımlarının belirlenmesine yönelik geçerli ve güvenilir ölçümler yapan bir ölçek geliştirilmesi amaçlanmıştır. Ölçeğin geçerlik ve güvenirlilk analizleri sonucunda 5'li likert tipinde 37 maddeden oluşan bir ölçme aracı geliştirilmiştir. Ölçme aracının geçerliliğini belirlemeye yönelik AFA sonuçları ölçeğin, "programa bağlılık", "sınav odaklı uyarlama", "öğrenci odaklı uyarlama" ve "programın tasarlanması" olmak üzere dört boyuttan oluştuğunu göstermiştir. Ölçeğin güvenirliğini belirlemeye yönelik yapılan analizler sonucunda her bir faktör için hesaplanan Cronbach alfa katsayılarının 0.82 ile 0.90 arasında değiştiği görülmüştür. Cronbach alfa katsayısının 0.70 ve üstü olduğu durumlarda ölçeğin güvenilir olduğu kabul edilmektedir (Durmuş, Yurtkoru ve Çinko, 2011). Ayrıca alt ölçekler bazında ölçeğin madde-toplam korelasyonu ve alt ölçekler korelasyonu için yapılan analizler de ölçeğin güvenirlik koşullarını sağladığını göstermektedir.

Ölçeğin alt boyutlarının isimlendirilmesinde program uygulama yaklaşımları ile ilgili literatürden (BenPeretz, 1990; Bümen, Çakar ve Yıldız, 2014; Çeliker-Ercan, 2019; Çobanoğlu, 2011; Drake ve Sherin, 2006; Dusenbury, Brannigan, Falco, Hansen, 2003; Kabaoğlu, 2015; Kaya, Çetin ve Yıldırım, 2012; Shawer, Gilmore ve Banks-Joseph, 2008; Snyder, Bolin ve Zumwalt, 1992; Tokgöz, 2013) ve araştırmacı tarafından ölçek maddelerinin yazılması öncesinde gerçekleştirilen nitel araştırma bulgularından faydalanılmıştır. AFA sonucunda, her maddenin teorik olarak kendi faktörü altında yer aldığı ve ortaya çıkan faktör yapısının konu ile ilgili teoriye uygun olduğu görülmektedir. Bu çalışmada öğretmenlerin program uygulama yaklaşımları programa bağııık düzeyleri dikkate alınarak belirlenmiştir. Programa bağııık, uzmanlar tarafından tasarlanan öğretim programının aslına sadık kalarak uygulanmasıdır (Bümen, Çakar ve Yıldız, 2014). Araştırma kapsamında programa bağlılık kavramı, tasarlanan program doğrultusunda hazırlanan program materyallerine (ders kitabı, öğretmen kılavuz kitabı ve öğrenci çalışma kitabı) bağııık olarak ele alınmıştır. Program materyalleri denildiğinde genellikle ders kitapları akla gelmektedir, fakat ders kitapları program materyallerinin sadece bir ögesini oluşturur (Ben-Peretz, 1990). Öğretmenlerin program uygulama yaklaşımlarının belirlenmesinde programın bir bileşenini oluşturan ders kitapları önemli bir yer tutmaktadır (Shawer, 2010). Ders kitapları, hangi konuların hangi sıra ile öğretileceğini ve her bir konuya ayrılacak süreyi belirledikleri için resmi öğretim programını tanımlar (Freeman ve Porter, 1989; Yıldırım, 2006) ve bu nedenle resmi öğretim programını temsil ederler (Elliott, 1990). Geliştirilen programlar doğrultusunda ders kitapları hazırlanır ve dağıtılır. Dahası Türkiye'de merkeziyetçi bir anlayışla geliştirilen öğretim programları kapsamında MEB tarafından hazırlanan ders kitapları tüm öğrencilere dağıtılır ve öğretmenlerin yalnızca bu kitapları kullanmaları beklenir. Bu nedenle programa bağlılık yaklaşımını benimseyen öğretmenler bu kitaplardaki içerik ve etkinlikleri bire bir uygulayıp, ekstra başka bir kaynak ya da etkinliğe yer vermezken, programı uyarlayan öğretmenler, öğrenci ilgi, istek, ihtiyaç ve beklentileri doğrultusunda bu kitaplardaki içerik ve etkinliklerde değişiklik yapma ya da ek kaynak ve etkinlikler kullanma eğilimindedirler. Bu nedenle öğretmenlerin program uygulama yaklaşımlarını belirlerken programın felsefesine uygun davranış sergileyip sergilememeleri dışında MEB tarafından hazırlanan ders kitaplarına sınıflarında nasıl yer verdiklerinin de incelenmesi faydalı olacaktır. Bu araştırma kapsamında ölçeğin her bir boyutu altında en yüksek faktör yüküne sahip maddeler incelendiğinde, her bir boyutun teoriye uygun olduğu görülmektedir. Programa bağlılık boyutu, öğretmenlerin program uygulamalarında ingilizce dersi 
öğretim programına ve MEB kaynaklarına bağlı kalarak ve hiçbir değişiklik yapmadan sınıftaki uygulamalarını yürüttüklerine dair ifadelere yer verirken; öğrenci odaklı ve sınav odaklı uyarlama yaklaşımları boyutlarında, öğretmenlerin sınıftaki program uygulamalarında MEB kaynaklarını dikkate aldıklarını, fakat bununla beraber öğrenci özellikleri ya da sınav başarısı odaklı bu kaynaklarda uyarlamalar yaptıklarını belirten ifadeler yer almaktadır. Son olarak programın tasarlanması boyutunda, öğretmenlerin sınıftaki program uygulamalarında resmi öğretim programından farklı uygulamalara yer verdiklerini ve MEB kaynaklarını kullanmadıklarını belirten ifadeler yer almaktadır. Burada programın tasarlanması olarak yapılan isimlendirme, öğretim programına ve öğretim programı kapsamında MEB kaynaklarına başvurulmadığını vurgulamak amacıyla yapılmışı. Aslında tasarlama süreci daha çok öğretim sürecine aittir. Yani programın tasarlanması yaklaşımı altında öğretmen baştan bir program tasarısı oluşturmamakta, fakat bununla birlikte, çalıştığı özel kurumun kendisine verdiği esneklik ile birlikte öğretimde resmi öğretim programından çok farklı bir şekilde bir tasarım gerçekleştirebilmektedir.

Dört boyut altında ölçekte yer alan ifadeler için (1) Asla, (2) Nadiren, (3) Bazen, (4) Sıklıkla, (5) Her zaman olacak şekilde 5'li Likert tipi bir derecelendirme kullanılmıştır. Ölçekte yer alan 1., 2., 8. ve 29. maddeler ters puanlanmaktadır. Ölçeğin tamamından toplam bir puan alınamamakla birlikte alt ölçeklerden alınan puan, öğretmenlerin söz konusu alt ölçekte ifade edilen yaklaşıma sahip olma düzeyini göstermektedir. Öğretmenlerin programa bağlılık alt ölçeğinden alabilecekleri minimum puan 6 iken en yüksek puan $30^{\prime}$ dur. Öğrenci odaklı uyarlama alt ölçeğinden alabilecekleri minimum puan 12 iken en yüksek puan $60^{\prime}$ tır. Sınav odaklı uyarlama alt ölçeğinden alabilecekleri minimum puan 10 iken en yüksek puan $50^{\prime}$ dir. Son olarak öğretmenlerin programın tasarlanması alt ölçeğinden alabilecekleri minimum puan 9 iken en yüksek puan $45^{\prime}$ tir. Alt ölçeklerden alınan puanın artması öğretmenlerin söz konusu yaklaşıma eğilim gösterme düzeylerinin de arttı̆̆ını ifade etmektedir.

Ölçeğe ilişkin yapılan geçerlik ve güvenirlik analizleri sonuçları, ortaokul íngilizce öğretmenlerinin program uygulama yaklaşımlarını belirlemeye yardımcı geçerli ve güvenilir ölçümler üretilen bir ölçme aracının geliştirildiğini göstermektedir. Geliştirilen bu ölçeğin, öncelikle programın uygulanması ile ilgili alanyazına katkı sağlayacağı ve bu ölçek yardımıyla öğretmenlerin program uygulama yaklaşımlarının geniş kitlelerde belirlenerek bu yaklaşımların öğretmen, öğrenci ve okul üzerindeki etkilerinin incelenmesine yönelik ileri araştırmaların önünü açacağı düşünülmektedir. Bu ölçeğin farklı şehir ve sınıf kademelerinde öğretim yapan İngilizce öğretmenleri ile uygulanması ölçeğin geçerliğine ve güvenilirliğine yönelik verilere katkı sağlayacaktır. Bunun yanı sıra ölçek maddelerinin farklı konu alanlarına uyarlanarak uygulanması da öğretmenlerin farklı derslerdeki program uygulama yaklaşımlarına yönelik araştırmalara yön verecektir. Bu araştırmada katılımcı sayısı sınırlıı̆̆ı nedeniyle doğrulayıcı faktör analizi gerçekleştirilememiştir. Bu nedenle ileri araştırmalarda doğrulayıcı faktör analizi yapılarak test tekrar test güvenirliğinin incelenmesi ölçeğin geçerliğine ve güvenirliğine yönelik verileri güçlendirmede önemli görülmektedir.

“Yükseköğretim Kurumları Bilimsel Araştırma ve Yayın Etiği Yönergesinde' yer alan tüm kurallara uyulmuş ve yönergenin ikinci bölümünde yer alan "Bilimsel Araştırma ve Yayın Etiğine Aykırı Eylemlerden" hiçbiri gerçekleştirilmemiştir.

\section{References}

Adıgüzel, A. (2009). Yenilenen ilköğretim programının uygulanması sürecinde karşılaşılan sorunlar. Mehmet Akif Ersoy Üniversitesi Eğitim Fakültesi Dergisi, 9(17), 77-94. Retrieved from https://www.researchgate.net

Akpınar, M. (2011). Illköğretim altıncı sınıf sosyal bilgiler öğretim programı, uygulanması ve seviye belirleme sınavı ile ilişkisinin incelenmesi. (Yayınlanmamıs doktora tezi). Atatürk Üniversitesi, Erzurum.

Aydemir, H. (2011). Ilköğretim 7. sınıf sosyal bilgiler öğretim programı etkinliklerinin uygulamadaki etkililiğinin değerlendirilmesi. (Yayınlanmamış doktora tezi). Fırat Üniversitesi, Elazı̆̆.

Aykaç, N. ve Ulubey, Ö. (2012). Öğretmen adaylarının ilköğretim programının uygulanma düzeyine ilişkin görüşleri. Ankara Üniversitesi Eğitim Bilimleri Fakültesi Dergisi, 45(1), 63-82. Retrieved from 
ÇELIKER ERCAN \& ÇUBUKÇU - Çukurova Üniversitesi Eğitim Fakültesi Dergisi, 50(2), 2021, 1464-1490

http://web.b.ebscohost.com/ehost/pdfviewer/pdfviewer?vid=0\&sid=5cd1bd3a-1080-451c-8d2264d84f458036\%40sessionmgr103

Ben-Peretz, M. (1990). The teacher-curriculum encounter. Freeing teachers from the tyranny of texts. Albany: State University of New York.

Bümen, N. T., Çakar, E. ve Yıldız, D. G. (2014). Türkiye'de öğretim programına bağlılık ve bağlıı̆ı etkileyen etkenler.Kuram ve Uygulamada Eğitim Bilimleri Dergisi, 14(1), 203-228. DOI: 10.12738/estp.2014.1.2020

Can, A. (2013). SPSS ile bilimsel araştırma sürecinde nicel veri analizi. Ankara: Pegem.

Çeliker-Ercan, G. (2019). Ortaokul Ingilizce öğretmenlerinin program uygulama yaklaşımlarının öğrencilerin motivasyonlarına ve akademik başarılarına etkisi (Yayınlanmamış doktora tezi). Eskişehir Osmangazi Üniversitesi, Eskişehir.

Çobanoğlu, R. (2011). Okul öncesi eğitimde eğitim programı uygulamasının yordayıcıları olarak öğretmen özyeterlik ve öğretmenlik inançları. (Yayınlanmamış Yüksek Lisans Tezi). Orta Doğu Teknik Üniversitesi, Sosyal Bilimler Enstitüsü.

Çokluk, Ö., Şekercioğlu, G. ve Büyüköztürk, Ş. (2014). Sosyal bilimler için çok değişkenli istatistik: SPSS ve Lisrel Uygulamaları. Ankara: Pegem.

Doll, R. C. (1970). Curriculum Improvement: Decision-Making and Process (Second Edition). Boston: AUyn and Bacon Inc.

Drake, C. \& Sherin, M. G. (2006). Practicing change: Curriculum adaptation and teacher narrative in the context of mathematics education reform. Curriculum Inquiry, 36(2), 153-187. https://doi.org/10.1111/j.1467-873X.2006.00351.X

Durmuş, B., Yurtkoru, E. S. ve Çinko, M. (2011). Sosyal bilimlerde SPSS'le veri analizi. İstanbul: Beta.

Dusenbury, L., Brannigan, R., Falco, M. \& Hansen, W. B. (2003). A review of research on fidelity of implementation: Implications for drug abuse prevention in school settings. Health Education Research, 18(2), 237-256. doi: 10.1093/her/18.2.237.

Elliot, D. (1990). Textbooks and the curriculum in the post-war era: 1950-1980. In D. Elliot \& A. Woodward (Ed.), In Textbooks and schooling in the United States: Eighty-ninth yearbook of the National Society for the Study of Education (p. 42-55). Chicago: Chicago University Press.

Field, A. (2009). Discovering statistics using SPSS (Third edition). Londan: Sage.

Freeman, D., J., \& Porter, A., C. (1989). Do textbooks dictate the content of mathematics instruction in elementary schools? American Educational Research Journal, 26(3), 403-421. https://doi.org/10.3102/00028312026003403

Fullan, M. \& Pomfret, A. (1977). Research on curriculum and instruction implementation. Review of Educational Research, 47(2), 335-397. Doi: 10.3102/00346543047002335

George, D. \& Mallery, P. (2016). IBM SPSS statistics 23, Step by Step: A Simple Guide and Reference (14 ${ }^{\text {th }}$ edition). New York: Routledge.

Gökçek, T. (2008). Altıncı sınıf matematik öğretmenlerinin yeni ilköğretim programına uyum sürecinin incelenmesi. (Yayınlanmamış doktora tezi). Karadeniz Teknik Üniversitesi, Trabzon.

Green, S. \& Salkind, N. (2005). Using SPSS for Windows and Macintosh: Understanding and analysing data $\left(4^{\text {th }}\right.$ edition). New Jersey: Pearson.

Gürel, E. ve Demirhan-işcan, C. (2020). Reviewing the 9th Grade English Curriculum with Stake's Responsive Evaluation Model ccording to Teachers Opinions, 49(1), 501-554. DOI: 10.14812/cufej.623396.

Kabaoğlu, K. (2015). Predictors of curriculum implementation level in elementary mathematics education: mathematics-related beliefs and teacher self-efficacy beliefs (Unpublished master thesis). Middle East Technical University. 
Kalaycı, Ş. (2010). SPSS uygulamalı çok değişkenli istatistik teknikleri (5. Baskı). Ankara: Asil.

Karacaoğlu, Ö. C. ve Acar, E. (2010). Yenilenen programların uygulanmasında öğretmenlerin karşılaştı̆̆ı sorunlar. Yüzüncü Yıl Üniversitesi Eğitim Fakültesi Dergisi, 7(1), 45-58. Retrieved from https://dergipark.org.tr/tr/pub/yvuefd/issue/13709/165979

Karadağ, E. (2009). Türkiye'de eğitim bilimleri alanında yapılmış doktora tezlerinin tematik ve metodolojik açıdan incelenmesi; Bir durum çalışması (Yayınlanmamış doktora tezi). Marmara Üniversitesi, İstanbul.

Kaya, E., Çetin, P. S. ve Yıldırım, A. (2012). Transformation of centralized curriculum into classroom practice: An analysis of teachers' experiences. Uluslararası Eğitim Programları ve Öğretim Çalışmaları Dergisi, 2(3), 103-113. Retrieved from http://ijocis.com/index.php/ijocis/article/view/75

Kline, P. (2014). An easy guide to factor analysis. Routledge.

Meidl, T. \& Meidl, C. (2011). Curriculum integration and adaptation: Individualizing Pedagogy for Linguistically and Culturally Diverse Students. Current Issues in Education, 14(1), 1-30.

Saraç, E. ve Yıldırım, M. S. (2019). 2018 Fen Bilimleri dersi öğretim programına yönelik öğretmen görüşleri. Academy Journal of Educational Sciences, 3(2), 138-151. https://doi.org/10.31805/acjes.641002

Shawer, S. F., Gilmore, D. \& Banks-Joseph, S. R. (2008). Student cognitive and affective development in the context of classroom-level curriculum development. Journal of the Scholarship of Teaching and Learning, 8(1), 1-28. Retrieved from https://eric.ed.gov/?id=EJ854820

Shawer, S. F., Gilmore, D. \& Banks-Joseph, S. R. (2009). Learner-Driven EFL Curriculum Development at the Classroom Level. International Journal of Teaching and Learning in Higher Education, 20(2), 125143. Retrieved from https://eric.ed.gov/?id=EJ864331

Shawer, S. F. (2010). Classroom-level curriculum development: EFL teachers as curriculum-developers, curriculum-makers and curriculum-transmitters. Teaching and teacher education, 26(2), 173-184. https://doi.org/10.1016/j.tate.2009.03.015

Snyder, J., Bolin, F. \& Zumwalt, K. (1992). Curriculum implementation. In P.W. Jackson (Ed.), Handbook of research on curriculum (p. 402-435). New York: Macmillan.

Şeker, S. (2007). Yeni fen ve teknoloji öğretim programının öğretmen görüşleri ışığında değerlendirilmesi (Gümüşhane Illi Örneği). (Yayınlanmamış yüksek lisans tezi). KTÜ Fen Bilimleri Enstitüsü, Trabzon

Şencan, H. (2005). Sosyal ve davranışsal ölçümlerde güvenilirlik ve geçerlilik. Ankara: Seçkin.

Tekbıyık, A. ve Akdeniz, A. R. (2008). illköğretim fen ve teknoloji dersi öğretim programını kabullenmeye ve uygulamaya yönelik öğretmen görüşleri. Necatibey Eğitim Fakültesi Elektronik Fen ve Matematik Eğitimi Dergisi, 2(2), 23-37. Retrieved from https://dergipark.org.tr/tr/pub/balikesirnef/issue/3367/46487

Tokgöz, Ö. (2013). Transformation of centralized curriculum into teaching and learning processes: Teachers' journey of thought curriculum into enacted one (Unpublished doctoral dissertation). Middle East Technical University, Ankara.

Yaşar, M. D. (2012). 9. Sınıf kimya öğretim programındaki yapılandırmacılığa dayalı öğelerin öğretmenler tarafından algılanışı ve uygulamasına yönelik bir inceleme: Erzurum örneği (Doktora tezi). Atatürk Üniversitesi, Erzurum.

Yıldırım, A. (2006). High school textbooks in Turkey from teachers' and students' perspectives: the case of history textbooks. Asia Pacific Education Review, 7(2), 218-228. https://link.springer.com/article/10.1007/BF03031545.

Yurdugül, H. (2012). Ölçek geliştirme çalışmalarında kapsam geçerlik indeksinin kullanımı. http://yunus.hacettepe.edu.tr/ yurdugul.pdf adresinden 15.05.2021 tarihinde indirilmiştir. 


\section{Öğretmenlerin Program Uygulama Yaklaşımları Ölçeği}

\begin{tabular}{|c|c|c|c|c|c|c|c|}
\hline 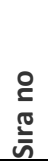 & $\begin{array}{l}\stackrel{2}{亡} \\
\frac{0}{0} \\
\frac{0}{0} \\
\stackrel{\pi}{\Sigma} \\
\end{array}$ & & $\frac{\pi}{4}$ & 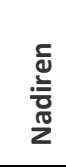 & 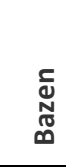 & 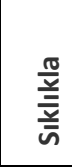 & 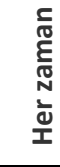 \\
\hline & & Programın Tasarlanması & & & & & \\
\hline 1 & 6 & Dersimi MEB kaynaklarından bağımsız planlarım. & 1 & 2 & 3 & 4 & 5 \\
\hline 2 & 11 & Dersimde MEB kaynaklarına başvurmadan, farklı bir kaynak kullanırım. & 1 & 2 & 3 & 4 & 5 \\
\hline 3 & 21 & Dersimde kullandığım içerik MEB kaynaklarındaki içerikten farklıdır. & 1 & 2 & 3 & 4 & 5 \\
\hline 4 & 14 & $\begin{array}{l}\text { Dersimde yer verdiğim kazanımlar MEB kaynaklarında yer alan kazanımlardan } \\
\text { farklıdır. }\end{array}$ & 1 & 2 & 3 & 4 & 5 \\
\hline 5 & 8 & Dersimde MEB kaynaklarını takip ederim. & 1 & 2 & 3 & 4 & 5 \\
\hline 6 & 2 & Dersimi planlarken MEB kaynaklarını** kullanırım. & 1 & 2 & 3 & 4 & 5 \\
\hline 7 & 55 & $\begin{array}{l}\text { Ölçme ve değerlendirme etkinliklerini MEB kaynaklarından bağımsız } \\
\text { gerçekleştiririm. }\end{array}$ & 1 & 2 & 3 & 4 & 5 \\
\hline 8 & 41 & $\begin{array}{l}\text { Dersimde yaptırdığım etkinlikler, MEB kaynaklarında bulunan etkinliklerden } \\
\text { farklıdır. }\end{array}$ & 1 & 2 & 3 & 4 & 5 \\
\hline \multirow[t]{2}{*}{9} & 1 & Dersimi planlarken İngilizce dersi öğretim programını* kullanırım. & 1 & 2 & 3 & 4 & 5 \\
\hline & & Öğrenci Odaklı Uyarlama & & & & & \\
\hline 10 & 38 & $\begin{array}{l}\text { Dersimde, MEB kaynaklarındaki etkinlikler dışında, oyun oynama, video izleme, } \\
\text { şarkı dinleme, yarışma gibi öğrencinin aktif olacağı ek etkinliklere yer veririm. }\end{array}$ & 1 & 2 & 3 & 4 & 5 \\
\hline 11 & 35 & $\begin{array}{l}\text { Dersimde yaptıracağım etkinlikleri öğrenci ilgi, istek ve ihtiyacı doğrultusunda } \\
\text { öğrenci ile birlikte şekillendiririm. }\end{array}$ & 1 & 2 & 3 & 4 & 5 \\
\hline 12 & 34 & $\begin{array}{l}\text { Kelime öğretiminde öğrencilerin eğlenerek öğrenmelerini sağlayacak öğrenci } \\
\text { odaklı etkinliklere yer veririm (oyun, yarışma, kelime keseleri hazırlama vb.). }\end{array}$ & 1 & 2 & 3 & 4 & 5 \\
\hline 13 & 36 & Dersimde yaptıracağım etkinliklerde öğrenciye seçme hakkı tanırım. & 1 & 2 & 3 & 4 & 5 \\
\hline 14 & 19 & $\begin{array}{l}\text { Dersimde, İngilizce dersi öğretim programında verilen tema dışında, öğrenci } \\
\text { profiline göre başka temalar da kullanırım. }\end{array}$ & 1 & 2 & 3 & 4 & 5 \\
\hline 15 & 53 & $\begin{array}{l}\text { Ölçme ve değerlendirme etkinliklerini düzenlerken öğrencilerin ileride günlük } \\
\text { hayatlarında işine yarayabilecek kazanımların ölçülmesine öncelik veririm. }\end{array}$ & 1 & 2 & 3 & 4 & 5 \\
\hline 16 & 37 & $\begin{array}{l}\text { Sınıfta öğrenme güçlüğü yaşayan ya da seviyesi düşük olan öğrenciler için farklı } \\
\text { etkinlikler düzenlerim. }\end{array}$ & 1 & 2 & 3 & 4 & 5 \\
\hline 17 & 9 & $\begin{array}{l}\text { Dersimde, MEB kaynaklarının yanı sıra, öğrencinin dikkatini çekecek ek kaynak } \\
\text { ve materyallere yer veririm (Örn; sunu (slayt), puzzle, video, flash kart, renkli } \\
\text { karton, eğlenceli çalışma kâğıtları vb.). }\end{array}$ & 1 & 2 & 3 & 4 & 5 \\
\hline 18 & 7 & $\begin{array}{l}\text { Sınıftaki etkinliklerde öğrencilerin kendi planlarını oluşturmalarına müsaade } \\
\text { ederim. }\end{array}$ & 1 & 2 & 3 & 4 & 5 \\
\hline 19 & 18 & $\begin{array}{l}\text { Dersimde, öğrenci isteği ve ihtiyacı doğrultusunda, MEB kaynaklarındaki içeriğin } \\
\text { dışında ek kelime ya da dil bilgisi kalıplarına yer veririm. }\end{array}$ & 1 & 2 & 3 & 4 & 5 \\
\hline 20 & 20 & Dersimde, MEB kaynaklarındaki içeriğin yanı sıra, öğrencinin ilgisini çekmeye & 1 & 2 & 3 & 4 & 5 \\
\hline
\end{tabular}


ÇELIKER ERCAN \& ÇUBUKÇU- Çukurova Üniversitesi Eğitim Fakültesi Dergisi, 50(2), 2021, 1464-1490

\begin{tabular}{|c|c|c|c|c|c|c|c|}
\hline & & yönelik güncel konulara ya da gündelik hayata ilişkin örneklere yer veririm. & & & & & \\
\hline \multirow[t]{2}{*}{21} & 13 & $\begin{array}{l}\text { Dersimde, İngilizce dersi öğretim programında yer alan kazanımlar dışında, } \\
\text { öğrenci ilgi ve ihtiyacı doğrultusunda, farklı kazanımlara da yer veririm. }\end{array}$ & 1 & 2 & 3 & 4 & 5 \\
\hline & & Sınav Odaklı Uyarlama & & & & & \\
\hline 22 & 16 & $\begin{array}{l}\text { Kazanımlar içerisinden, merkezi sınavlarda ağırlıklı olarak ölçülen beceri } \\
\text { alanlarına dersimde daha fazla yer veririm. }\end{array}$ & 1 & 2 & 3 & 4 & 5 \\
\hline 23 & 40 & $\begin{array}{l}\text { Öğrencileri merkezi sınava hazırlamak amacıyla sınıfta dil bilgisi konu anlatımına } \\
\text { ve pekiştirilmesine yönelik ek alıştırmalar yaparım. }\end{array}$ & 1 & 2 & 3 & 4 & 5 \\
\hline 24 & 23 & $\begin{array}{l}\text { Dersimde, MEB kaynaklarında yer alan bilgilerden merkezi sınavda çıkması } \\
\text { muhtemel olanlara ağırlık veririm. }\end{array}$ & 1 & 2 & 3 & 4 & 5 \\
\hline 25 & 47 & Dersimde yaptırdığım etkinliklerde sınavda çıkacak kısımları vurgularım. & 1 & 2 & 3 & 4 & 5 \\
\hline 26 & 39 & $\begin{array}{l}\text { Ders kitabındaki etkinlikler öğrencileri merkezi sınava hazırlamaya yetersiz } \\
\text { kaldığı için sınıfta ek alıştırmalar yaptırırım (çoktan seçmeli test, çalışma kâğıdı } \\
\text { vb.). }\end{array}$ & 1 & 2 & 3 & 4 & 5 \\
\hline 27 & 10 & $\begin{array}{l}\text { Dersimde, MEB kaynaklarının yanında, öğrencileri merkezi sınava hazırlamaya } \\
\text { yardımcı ek kaynaklar kullanırım (Örn; çalışma kâğıdı, fotokopi, test vb.). }\end{array}$ & 1 & 2 & 3 & 4 & 5 \\
\hline 28 & 54 & $\begin{array}{l}\text { Değerlendirme süreçlerinde merkezi sınavlara hazırlık amacıyla çoktan seçmeli } \\
\text { sorulara yer veririm. }\end{array}$ & 1 & 2 & 3 & 4 & 5 \\
\hline 29 & 46 & $\begin{array}{l}\text { Öğrencileri merkezi sınavlara hazırlamak amacıyla dersimde dil bilgisi anlatımına } \\
\text { ağırlık veririm. }\end{array}$ & 1 & 2 & 3 & 4 & 5 \\
\hline 30 & 5 & Dersimi bir üst kademeye geçiş sınavına hazırlayıcı olacak şekilde planlarım. & 1 & 2 & 3 & 4 & 5 \\
\hline \multirow[t]{2}{*}{31} & 48 & $\begin{array}{l}\text { Dersimde gerçekleştirdiğim öğretim, merkezi sınavı ya da dersi geçmeye } \\
\text { yöneliktir. }\end{array}$ & 1 & 2 & 3 & 4 & 5 \\
\hline & & Programa Bağlılık & & & & & \\
\hline 32 & 26 & $\begin{array}{l}\text { Dersimde MEB kaynaklarındaki etkinlikleri, hiçbir değişiklik yapmadan, } \\
\text { belirtildiği şekilde uygularım. }\end{array}$ & 1 & 2 & 3 & 4 & 5 \\
\hline 33 & 24 & Ders kitabını, ünite ünite, sayfa sayfa, sırası ile eksiksiz bir şekilde işlerim. & 1 & 2 & 3 & 4 & 5 \\
\hline 34 & 45 & $\begin{array}{l}\text { Öğrenci profiline uygun olmasa bile, mecburiyetten dolayı MEB kaynaklarındaki } \\
\text { tüm etkinlikleri değiştirmeden aynen uygularım. }\end{array}$ & 1 & 2 & 3 & 4 & 5 \\
\hline 35 & 25 & $\begin{array}{l}\text { Dersimde MEB kaynaklarındaki etkinlikleri sırası ile yaptırdığım için bir sonraki } \\
\text { derste ne öğreteceğim ve hangi etkinlikleri yaptıracağım bellidir. }\end{array}$ & 1 & 2 & 3 & 4 & 5 \\
\hline 36 & 29 & $\begin{array}{l}\text { Öğrenci seviyesine uygun olmadığında ders kitabındaki etkinliklerde atlama ya } \\
\text { da değişiklik yaparım. }\end{array}$ & 1 & 2 & 3 & 4 & 5 \\
\hline 37 & 17 & Dersimde, MEB kaynaklarındaki içeriği hiçbir değişiklik yapmadan kullanırım. & 1 & 2 & 3 & 4 & 5 \\
\hline
\end{tabular}

